\title{
De Nederlandse lucht- en ruimtevaart: een uitdaging voor (jonge) werkzoekenden?
}

Citation for published version (APA):

Borghans, L., Heijke, J. A. M., \& Golsteyn, B. H. H. (2003). De Nederlandse lucht- en ruimtevaart: een uitdaging voor (jonge) werkzoekenden? Researchcentrum voor Onderwijs en Arbeidsmarkt, Faculteit der Economische Wetenschappen. ROA Reports No. 12 https://doi.org/10.26481/umarep.2003012

Document status and date:

Published: 01/01/2003

DOI:

10.26481/umarep.2003012

Document Version:

Publisher's PDF, also known as Version of record

\section{Please check the document version of this publication:}

- A submitted manuscript is the version of the article upon submission and before peer-review. There can be important differences between the submitted version and the official published version of record.

People interested in the research are advised to contact the author for the final version of the publication, or visit the DOI to the publisher's website.

- The final author version and the galley proof are versions of the publication after peer review.

- The final published version features the final layout of the paper including the volume, issue and page numbers.

Link to publication

\footnotetext{
General rights rights.

- You may freely distribute the URL identifying the publication in the public portal. please follow below link for the End User Agreement:

www.umlib.nl/taverne-license

Take down policy

If you believe that this document breaches copyright please contact us at:

repository@maastrichtuniversity.nl

providing details and we will investigate your claim.
}

Copyright and moral rights for the publications made accessible in the public portal are retained by the authors and/or other copyright owners and it is a condition of accessing publications that users recognise and abide by the legal requirements associated with these

- Users may download and print one copy of any publication from the public portal for the purpose of private study or research.

- You may not further distribute the material or use it for any profit-making activity or commercial gain

If the publication is distributed under the terms of Article $25 \mathrm{fa}$ of the Dutch Copyright Act, indicated by the "Taverne" license above, 
De Nederlandse lucht- en ruimtevaart: Een uitdaging voor (jonge) werkzoekenden?

ROA-R-2003/12

Lex Borghans

Bart Golsteyn

Hans Heijke

Researchcentrum voor Onderwijs en Arbeidsmarkt

Faculteit der Economische Wetenschappen en Bedrijfskunde Universiteit Maastricht

Maastricht, september 2003 
ISBN 90-5321-380-5

Sec03.020.doc 


\section{Inhoud}

Bladzijde

1 Inleiding 1

2 Individuele keuzes en de vraag naar personeel $\quad 7$

3 Werkgelegenheid in de cluster 19

4 De marktpositie van de Nederlandse lucht- en ruimtevaart 23

5 De keuze voor de lucht- en ruimtevaart 29

6 De ontwikkelingen bij Fokker $\quad 35$

7 Wat gebeurt er als de lucht- en ruimtevaart groter wordt? Een vergelijking met de VS 41

8 Conclusies en opzet van het vervolgonderzoek $\quad 47$

$\begin{array}{ll}\text { Literatuur } & 49\end{array}$ 



\section{Voorwoord}

Dit rapport, waarin een analyse wordt gemaakt van de arbeidsmarkt in de lucht- en ruimtevaart vanuit het perspectief van studie- en beroepskiezers, is geschreven in opdracht van stichting VNL. Auteurs van het rapport zijn Lex Borghans, Hans Heijke en Bart Golsteyn van het Researchcentrum voor Onderwijs en Arbeidsmarkt (ROA) van de Universiteit Maastricht. Ben Kriechel van BIRC, Universiteit Maastricht, heeft een bijdrage geleverd voor hoofdstuk 6 van dit rapport. Frank Cörvers van het ROA heeft meegewerkt bij de start van dit project en ook later nuttig commentaar geleverd. De totstandkoming van het rapport is door de VNL begeleid door A.L. de Jong en ir. G.J.W. Oldeman van VNL. Verder is het onderzoek regelmatig besproken met een begeleidingscommissie bestaande uit J.Z. Cislo (Fokker Aerostructures BV), drs. D.M.J. Habets (NLC), F. Jansen (NAG), Lkol. G.J. Kolkman (Koninklijke Luchtmacht), drs. G. Woelders (KLM) en W. Schrijver (Schiphol Group), zijn gesprekken gevoerd met J.Z. Cislo (Fokker Aerostructures BV), B. van Es (KLM), E. Houben-Huizinga (Maastricht-Aachen Airport) en E. van Meeuwen (KLM) en zijn tussentijdse resultaten besproken in een werkconferentie waaraan vele betrokkenen uit de cluster hebben deelgenomen. 



\section{Resumé}

In dit rapport worden de resultaten gepresenteerd van een vooronderzoek met betrekking tot de vraag of - met name bij een verdere groei van de cluster voldoende belangstelling zal bestaan onder de studie- en beroepskiezers voor de lucht- en ruimtevaart en hoe deze belangstelling gestimuleerd kan worden. Uitgangspunt van dit onderzoek is dat bij de analyses van de keuzes die mensen maken de loopbaan in zijn geheel in ogenschouw moet worden genomen. Als jonge mensen een opleiding kiezen, weten ze nog vrij weinig over wat het beroep waar zij voor kiezen werkelijk inhoud. Veel jongeren laten zich dan ook leiden door vage beelden over de latere beroepspraktijk. Als geprobeerd wordt de keuze voor opleidingen voor de lucht- en ruimtevaart te stimuleren loopt men dan ook het risico dat juist meer jongeren voor de opleiding kiezen, die naderhand zullen ontdekken dat dit voor hen de juiste keuze niet was. Het gevolg hiervan kan zijn dat men ontevreden is en wellicht de sector weer verlaat. De cruciale vraag is daarom hoe men jongeren kan stimuleren voor de sector te kiezen voor wie dit ook werkelijk een aantrekkelijk perspectief is.

In het rapport wordt een theoretisch kader uitgewerkt dat aan de hand van bestaande empirische gegevens en op basis van gesprekken met deskundigen uit de cluster wordt geanalyseerd. Uit deze analyses komt naar voren dat ongeveer $40 \%$ van de werkgelegenheid in de lucht- en ruimtevaart, functies betreft die vrij specifiek zijn voor de Nederlandse arbeidsmarkt. Het gaat hier met name om piloten en stewardessen en om technici. Daarnaast wijkt met name het werk bij de luchtvaartbedrijven en op de luchthavens qua arbeidsomstandigheden sterk af van het gemiddelde. De reisafstand is lang, er is veel sprake van onregelmatig werk, mensen hebben weinig invloed op de indeling van het werk, er is vaker dan normaal sprake van conflicten met klanten en men heeft meer dan gemiddeld last van gassen en dampen.

Voor zover de beschikbare gegevens het mogelijk maken hierover conclusies te trekken, komt uit de analyses naar voren dat het imago van de lucht- en ruimtevaart niet stelselmatig te gunstig of te ongunstig is. Hoewel de arbeidsvoorwaarden minder gunstig zijn dan in andere sectoren, zijn er grosso modo ongeveer evenveel jongeren die als ze eenmaal de arbeidsmarkt hebben betreden spijt hebben van hun keuze voor de lucht- en ruimtevaart, als dat er jongeren zijn die achteraf juist liever wel een studie in deze richting hadden willen volgen. Wel komen uit de analyses een aantal specifieke punten ten aanzien van bepaalde beroepsgroepen in de lucht- en ruimtevaart naar voren.

Allereerst duiden de onderzoeksresultaten er op dat de keuze van stewardessen voor dit beroep vrij sterk bepaald wordt door een voorliefde voor dit vak. Het lijkt er echter op dat men vaak niet goed precies weet wat het beroep inhoud. Meer dan de helft van de schoolverlaters van de MBO-opleiding heeft na anderhalf jaar spijt van de opleiding. Vrij grote aantallen opgeleide stewardessen gaan na verloop van tijd buiten de lucht- en ruimtevaart werken. Als duidelijk zou worden welke factoren bepalend zijn voor een bewustere keuze voor het beroep stewardess zouden 
opleidingskosten bespaard kunnen worden en zou deze snelle uitstroom vermeden kunnen worden. Uit een vergelijking met de Verenigde Staten komt verder naar voren dat als de vraag naar personeel verder stijgt, het snel moeilijker zal worden om stewardessen te werven, omdat de groep met een sterke voorkeur voor dat vak snel te klein wordt. Ook is de gemiddelde leeftijd van stewardessen in de VS veel hoger dan in Nederland. De consequentie zal zijn dat bij een groei van de luchtvaart met name de lonen van stewardessen zullen moeten stijgen en dat maatregelen genomen zullen moeten worden om stewardessen tot op latere leeftijd werkzaam te houden.

De situatie met betrekking tot de technici is van totaal ander aard. De analyses wijzen uit dat de meeste technisch geïnteresseerden geen sterke voorkeur voor de lucht- en ruimtevaart hebben. Dit betekent - zeker op langere termijn - dat een groeiende vraag naar technisch personeel vrij makkelijk opgevangen kan worden, omdat de lucht- en ruimtevaart feitelijk deel uitmaakt van een veel groter arbeidsmarktsegment van technici. De keerzijde hiervan is echter wel dat veel technisch opgeleiden vrij makkelijk de sector verlaten om elders te gaan werken. Zo gaat bijvoorbeeld een zeer groot deel van de afgestudeerden van luchtvaarttechniek uit Delft werken bij een technisch bedrijf dat niet in de lucht- en ruimtevaart actief is. Ook is een groot deel van de ex-Fokker-medewerkers naar een technisch bedrijf in een andere sector vertrokken. De lucht- en ruimtevaart moet dus concurreren met andere technische bedrijven. Zeker als de winstmarges klein zijn en daardoor de mogelijkheden om de arbeidsvoorwaarden te verbeteren beperkt zijn, kan dit makkelijk tot knelpunten in de personeelsvoorziening leiden.

Tot slot valt op dat in de Verenigde Staten - waar de loonflexibiliteit veel groter is dan in Nederland - met name de ongeschoolden in de luchtvaart veel minder verdienen dan in andere sectoren. Dit wijst erop dat de luchtvaart in de VS werkgelegenheid biedt aan juist de ongeschoolden die elders het moeilijkst werk kunnen vinden. Door de relatief ongunstige werkomstandigheden in de luchtvaart en de minder flexibele loonstructuur in Nederland, dringt zich hierbij de vraag op in hoeverre ook de luchtvaart in Nederland een interessante optie is voor degenen met de laagste kwalificaties.

Op grond van de resultaten in dit rapport wordt voorgesteld om juist voor de drie genoemde groepen (stewardessen, hoog opgeleiden technici en de laagstgeschoolden) in het hoofdonderzoek op basis van een enquête meer zicht te krijgen op het beeld dat men heeft van werken in de lucht- en ruimtevaart voordat men gaat studeren, de wijze waarop dit beeld tot stand komt en de latere ervaringen met het werk in de lucht- en ruimtevaart. Op basis van een deze enquête kan dan nader worden geanalyseerd welke factoren cruciaal zijn voor het verder stimuleren van het aanbod voor de lucht- en ruimtevaart. 


\section{Inleiding}

Vliegtuigen, helikopters en raketten oefenen op velen een grote aantrekkingskracht uit. Heel veel jongens bouwen als kind vliegtuigjes en roepen dat ze later piloot zullen worden, terwijl menig meisje er van droomt later stewardess te worden. Het is duidelijk dat - zeker bij jonge mensen - de lucht- en ruimtevaart tot de verbeelding spreekt. Aan de andere kant wordt, door de sterk toegenomen schaal, de luchtvaart steeds meer een bedrijfstak als vele anderen en komt de lucht- en ruimtevaart met het faillissement van Fokker, ongelukken en milieuproblemen ook steeds vaker negatief in het nieuws. De beeldvorming bij de (jonge) studiekiezer of werkzoekende lijkt daarom voor de lucht- en ruimtevaart van cruciale betekenis voor de personeelswerving.

Deze specifieke situatie roept de vraag op, hoe bedrijven in de lucht- en ruimtevaart, met name in de situatie waarin de vraag naar nieuw personeel groot is, de keuze voor werken in deze cluster kunnen stimuleren. In dit rapport zal worden ingegaan op de vraag hoe in de lucht- en ruimtevaart de studie- en beroepskeuze samenhangt met arbeidsmarktontwikkelingen en welke rol percepties en mispercepties hierin spelen. Doel is om op basis van beschikbare literatuur en cijfermateriaal in kaart te brengen welke aspecten bij het keuzeproces ten aanzien van de lucht- en ruimtevaart het meest in het oog springen. In een vervolgonderzoek kunnen op basis van deze inzichten door middel van een enquête de motieven en afwegingen die spelen bij de keuze voor deze cluster nader worden geanalyseerd.

Vanuit dit perspectief wordt in dit rapport een verkennende analyse gemaakt van de arbeidsmarkt van de lucht- en ruimtevaart. Hierbij staan drie vragen centraal. Allereerst speelt de vraag wat er precies onder de arbeidsmarkt voor de lucht- en ruimtevaart moet worden verstaan. In de lucht- en ruimtevaart is er sprake van zeer uiteenlopende activiteiten, waar mensen werken in talloze beroepen en met een zeer uiteenlopende opleidingsachtergrond. De vraag is dus in hoeverre er sprake is van een specifiek arbeidsmarktprobleem voor de lucht- en ruimtevaart. De tweede vraag die aan de orde komt is of er op deze arbeidsmarkt sprake is van knelpunten in de personeelsvoorziening en of een slecht imago of ongunstige arbeidsvoorwaarden er toe leiden dat minder mensen belangstelling krijgen voor een loopbaan in de luchten ruimtevaart dan verwacht zou mogen worden. De derde vraag die aan de orde komt is welke ontwikkelingen op de arbeidsmarkt voor de lucht- en ruimtevaart verwacht kunnen worden, als deze sector verder gaat groeien. Met een verdere groei van de sector zal immers een relatief steeds groter deel van de bevolking bereid gevonden moeten worden in de lucht- en ruimtevaart te gaan werken. Dit betekent dat reeds bestaande knelpunten mogelijk nog groter zullen worden, maar ook dat steeds meer een beroep moet worden gedaan op mensen die minder affiniteit met de sector hebben dan degenen voor wie werken in de lucht- en ruimtevaart een droomloopbaan is.

In het kader van dit vooronderzoek zijn gesprekken gevoerd met deskundigen uit het werkveld, heeft een verkenning van de literatuur over studie- en beroepskeuze 
plaatsgevonden en zijn de beschikbare relevante statistische gegevens over de arbeidsmarkt in de cluster verkend en geanalyseerd. De resultaten van deze verkenning zijn meerdere malen besproken met de begeleidingscommissie waarin een aantal belangrijke vertegenwoordigers uit het onderwijs en het werkveld zitting heeft. Verder is er naar aanleiding van de voorlopige bevindingen van het onderzoek een werkconferentie georganiseerd waarin een grote groep belangstellenden de uitkomsten heeft bediscussieerd. Zowel de literatuurverkenning en de statistische analyses als de inzichten uit deze gesprekken en bijeenkomsten hebben samen de basis gevormd voor dit rapport.

Op grond van de bevindingen uit de literatuurverkenning, de statistische analyses en de gesprekken met deskundigen en betrokkenen worden in het laatste hoofdstuk van dit rapport een aantal belangrijke aandachtspunten genoemd over de studie- en beroepskeuze die typisch zijn voor de lucht- en ruimtevaart. Op basis van deze aandachtspunten wordt een voorstel geformuleerd voor verder onderzoek naar de manier waarop de keuze voor de lucht- en ruimtevaart tot stand komt, om daarmee het beleid op dit gebied nieuwe aanknopingspunten te bieden.

\section{Belang van lucht- en ruimtevaart}

Uiteraard is de lucht- en ruimtevaart niet de enige sector waarbij de werving van voldoende geschikt personeel een aandachtsgebied is. Een goede personeelsvoorziening voor de lucht- en ruimtevaart overstijgt echter de belangen van de bedrijven in deze cluster. De luchtvaart is een steeds grotere rol in de economische ontwikkeling van regio's en landen gaan spelen. Rondom een luchthaven ontwikkelt zich vaak een enorme bedrijvigheid die qua aantallen werknemers, maar ook qua aard van de activiteiten de kernactiviteiten in de luchtvaart vele malen overtreffen. ${ }^{1}$ Studies hebben laten zien dat luchthavens enorme werkgelegenheidseffecten voor de regio met zich mee brengen en wie bijvoorbeeld in de buurt van Schiphol rondkijkt ziet dat niet alleen duidelijk luchtvaart gerelateerde bedrijven, maar ook talloze andere bedrijven variërend van de winkels rondom Schiphol tot het kantoor van een accountant hun locatie in de buurt van de luchthaven hebben gekozen. De grote betekenis van een luchthaven is overigens niet in eerste instantie gelegen in deze opbloeiende werkgelegenheid, maar in de waarde van een adequate infrastructuur voor de mensen en bedrijven in de betreffende regio. Men kan beargumenteren dat als er geen luchthaven zou zijn geweest andere werkgelegenheid tot ontwikkeling zou zijn gekomen. Uit het feit dat veel bedrijven zich juist graag vestigen in de buurt van een luchthaven, of in een stad of regio die beschikt over een luchthaven met verbindingen naar vele plaatsen in de wereld, blijkt dat deze infrastructuur van grote waarde is voor de productiviteit van vele ondernemingen. ${ }^{2}$

1. Zie bijvoorbeeld Faber en Poort (2002) voor een analyse van de indirecte economische effecten van het lucht- en ruimtevaartcluster. Ook Koning, Verkade en Hakfoort (2002) gaan kort in op de indirecte effecten van Schiphol.

2. Ciccone en Hall (1996) laten zien dat een groot deel van de productiviteitsverschillen tussen gebieden (meestal dichtbevolkte versus dunbevolkte gebieden) verklaard kan worden door de beschikbare voorzieningen. 
Hoewel er in de maatschappelijke discussie en in de economische literatuur veel aandacht uitgaat naar de overlast die het luchtverkeer met zich mee kan brengen, komt uit economisch onderzoek ook zonder meer naar voren dat een goede luchtverkeerinfrastructuur een groot positief extern effect op de economische ontwikkelingen in de omgeving heeft. Veel regio's in de wereld zijn daardoor in een strategische strijd verwikkeld om er voor te zorgen dat men beschikt over een vooraanstaande luchthaven en proberen hun luchthaven een hub-functie te geven zodat de locale bevolking en de bedrijven kunnen profiteren van het uitgebreide netwerk aan verbindingen dat daardoor tot stand komt. ${ }^{3}$ Bij deze strategische ontwikkeling gaat het overigens niet om de luchthaven alleen, maar mogelijk ook om toeleveringsbedrijven en bedrijven die actief zijn op het gebied van productie en onderhoud van vliegtuigen.

Voor een land of regio dat een dergelijke strategische betekenis toekent aan de luchtvaart, kan het verminderen van belemmeringen voor de ontwikkeling van de sector van groot belang zijn. In dat licht ligt het voor de hand om ook belemmeringen op de arbeidsmarkt, zoals die hierboven zijn genoemd, zorgvuldig onder de loep te nemen. Als het immers mogelijk is om maatregelen te nemen waardoor de belangstelling voor werken in de luchtvaart wordt vergroot en bedrijven in de luchtvaart makkelijker aan personeel kunnen komen, ontstaat immers een comparatief voordeel voor de luchtvaart in deze regio ten opzichte van andere landen of regio's.

\section{Uitgangspunten van dit onderzoek}

Uit eerder onderzoek op het gebied van studie- en beroepskeuzeprocessen is naar voren gekomen dat de keuze om niet (meer) in een bepaalde sector te willen werken altijd gezien moet worden vanuit het perspectief van het gehele voorafgaande keuzetraject. Het kiezen van een opleiding of beroep is een moeilijk proces, en deze keuzes moeten gemaakt worden voordat dat de consequenties van deze keuzes goed overzien kunnen worden. Dit betekent dat er altijd mensen zullen zijn die zich vergissen en achteraf ontdekken dat ze eigenlijk de verkeerde keuze hebben gemaakt. Soms is dit geen groot probleem en weten mensen ook in de ingeslagen richting een interessante loopbaan op te bouwen. Vaak echter besluiten deze mensen achteraf de koers toch nog te verleggen en gaan ze in andere beroepen werken en volgen ze eventueel nog een nieuwe opleiding.

Als nu in onderzoek alleen wordt gekeken naar mensen die voor hun studiekeuze staan dan kunnen degenen die terecht voor een bepaalde opleiding kiezen en degenen die hier naderhand spijt van krijgen niet worden onderscheiden. Onderzoek naar deze groep levert dan ook geen beeld op van de redenen waarom mensen de betreffende opleiding interessant vinden, maar laat zien welke mensen deze opleiding interessant denken te vinden. Als men op grond van dergelijke bevindingen de belangstelling voor de sector wilt stimuleren, is het gevaar groot dat men juist

3. Zie Blonigen en Van Kolpin (2002). Volgens Jan Veldhuis (2002) neemt ook in Europa de concurrentie om de hub's toe. 
mensen aantrekt die naderhand inzien dat ze toch beter iets anders hadden kunnen kiezen.

Onderzoek kan zich ook richten op de motieven waarom sommige schoolverlaters niet doorstromen naar de betreffende sector of waarom werknemers na verloop van tijd de sector verlaten. Ook in dat geval is het gevaar groot dat men juist in beeld brengt waarom mensen de sector niet aantrekkelijk vinden die eigenlijk al niet voor deze richting hadden moeten kiezen.

Om adequaat het studie- en beroepskeuzeproces te kunnen analyseren moet daarom zowel in beeld worden gebracht hoe mensen als ze eenmaal werken hun reeds gemaakte keuzes beoordelen, als hoe zij destijds gekomen zijn tot hun keuze om al dan niet in de lucht- en ruimtevaartsector te willen werken. Als bijvoorbeeld als belangrijkste knelpunt naar voren komt dat schoolverlaters uit opleidingen die zich sterk op de lucht- en ruimtevaartsector richten hier toch niet gaan werken, is het niet alleen van belang om te weten wat op dat moment hun motieven zijn, maar ligt vooral de sleutel naar het beleid in de vraag waarom deze groep destijds wel voor deze opleiding heeft gekozen. Mogelijk had men verwachtingen over de opleiding die naderhand niet zijn uitgekomen. De percepties kwamen kennelijk niet overeen met de werkelijkheid. Omgekeerd kunnen er ook groepen zijn die vanwege negatieve percepties niet voor de lucht- en ruimtevaart kiezen, terwijl ze dit mogelijk wel hadden gedaan als ze een beter beeld van de cluster hadden gehad.

Om dus een gedetailleerde analyse te kunnen maken van de manier waarop de keuze tot stand komt om een opleiding gericht op de lucht- en ruimtevaart te gaan volgen of om in deze sector te gaan werken zal informatie verzameld moeten worden over zowel de afwegingen van mensen die bij hun keuzeproces hebben gespeeld als over de kijk die ze hebben op het werk in de lucht- en ruimtevaart als ze eenmaal werkzaam zijn. Het bestaande datamateriaal hierover is beperkt. Om die reden zal in een hoofdonderzoek een enquête worden gehouden waarin de informatie die nodig is voor de analyse van het keuzeproces systematisch wordt verzameld. Dit vooronderzoek heeft als doel om op basis van de beschikbare informatie de situatie in de lucht- en ruimtevaart in kaart te brengen, zodat duidelijk is op welke knelpunten de aandacht in het hoofdonderzoek gericht moet worden.

\section{Opzet rapport}

De opbouw van dit rapport - dat een overzicht geeft van de bevindingen van dit vooronderzoek - is als volgt. Allereerst zal in hoofdstuk 2 het theoretisch raamwerk worden geschetst van waaruit het keuzeproces van mensen het beste kan worden geanalyseerd. Kernpunt van dit theoretisch kader is dat zowel individuele voorkeuren als arbeidsmarktmogelijkheden een rol zullen spelen in het keuzeproces en mensen op basis van beperkte informatie hierover een keuze moeten maken. In hoofdstuk 3 wordt een beeld gegeven van de werkgelegenheid in de cluster. Vervolgens komt in hoofdstuk 4 de vraag aan de orde in hoeverre er sprake is van een aparte arbeidsmarkt voor de lucht- en ruimtevaart. Hierbij wordt zowel ingegaan op de aard van de 
werkzaamheden en de benodigde opleiding in de lucht- en ruimtevaart als op de omstandigheden waaronder het werk moet worden uitgevoerd. In hoofdstuk 5 wordt op basis van gegevens van schoolverlaters gekeken hoe de arbeidsmarktpositie van de lucht- en ruimtevaart is in vergelijking met andere bedrijven waar deze jongeren kunnen gaan werken en hoe de schoolverlaters terugblikken op de door hen gemaakte studiekeuze. In hoofdstuk 6 wordt ingegaan op de ontwikkelingen na het faillissement van Fokker, omdat ook hieruit interessante informatie naar voren komt over de positie van de lucht- en ruimtevaart ten opzichte van bedrijven die gebruik maken van personeel met een zelfde opleidingsachtergrond. In hoofdstuk 7 wordt de blik verlegd naar de Verenigde Staten. Het voornaamste doel hiervan is dat de verschillen in het belang van de lucht- en ruimtevaart in de verschillende regio's van de Verenigde Staten benut kunnen worden om een beeld te krijgen van wat er zal gebeuren als de lucht- en ruimtevaart in Nederland in omvang sterk zou gaan groeien. In hoofdstuk 8 worden de voornaamste bevindingen op een rij gezet en wordt een voorstel gedaan voor de opzet van het hoofdonderzoek. 



\section{Individuele keuzes en de vraag naar personeel}

Het is alleen mogelijk om op beleidsmatig invloed uit te oefenen op het keuzegedrag van individuen als er een relatie bestaat tussen maatregelen die de sector of de bedrijven nemen op het gebied van werving of arbeidsvoorwaarden en de studie- en beroepskeuze van mensen. De beslissing om een bepaalde opleiding te gaan volgen of een bepaald beroep te kiezen is echter een zeer persoonlijke keuze. Wie aan mensen vraagt waarom men voor een opleiding of beroep heeft gekozen komt er achter dat persoonlijke interesses en capaciteiten, maar ook toevallige ervaringen met dat vak, een grote rol kunnen spelen. Er is meestal weinig dat er op wijst dat mensen zich direct laten leiden door ontwikkelingen in de vraag op de arbeidsmarkt. Met name in de beroepskeuzeliteratuur wordt daarom nadrukkelijk gewezen op de onstuurbaarheid van studie- en beroepskeuzeprocessen. Meijers (1995) vergelijkt de studiekeuze met de keuze voor een huwelijkspartner. Hoewel het gaat om een van de belangrijkste beslissingen in het leven, speelt toeval een zeer grote rol en laten mensen zich niet van buitenaf zeggen met wie ze moeten trouwen. Het is in zijn ogen daarom ook een illusie om te verwachten dat de studiekeuze van jongeren gestuurd kan worden.

Als het studie- en beroepskeuzeproces echter van een wat grotere afstand wordt bestudeerd, blijken er toch duidelijke patronen in het gedrag van deze individuen te zitten. Diverse studies laten zien dat de totale belangstelling voor een bepaalde studierichting of beroep duidelijk reageert op de ontwikkelingen op de arbeidsmarkt. ${ }^{4}$ Zo zijn bijvoorbeeld, met de opkomst van de computer steeds meer mensen informatica gaan studeren. Deze veranderingen komen tot stand doordat werkgevers bij tekorten aan bepaalde groepen personeel hun arbeidsvoorwaarden ${ }^{5}$ en hun wervingsbeleid aanpassen en studenten hierop reageren. De verklaring waarom in de totale studentenstromen duidelijke patronen te vinden zijn terwijl de individuele keuzes zo sterk van toeval afhangen, is gelegen in het feit dat naast de grote invloed van toevalligheden, de feitelijke arbeidsmarktontwikkelingen ook een kleine rol spelen. Op individueel niveau is deze invloed nauwelijks te herkennen, maar geaggregeerd vallen de individuele toevalligheden tegen elkaar weg en blijft de onderliggende tendens over. Minder duidelijkheid is er over de precieze wijze waarop deze arbeidsmarktinvloed werkt. Economen als Siow (1984) en Zarkin $(1983,1985)$ be-

4. Zo laat Freeman in een aantal studies het verband zien tussen de loonsontwikkeling en de studiekeuze voor rechten (Freeman, 1975a), natuurkunde (Freeman, 1975b) en promotieplaatsen aan universiteiten (Freeman, 1980). Fiorito en Dauffenbach (1982) laten zien dat bij de keuze van de studierichting op de universiteit in de VS zowel lonen als inhoudelijke overwegingen een rol spelen. Hansen et al. (1980) en Huffman en Orazem (1985) laten dit zien voor de keuze van een Ph.D. Ook voor Nederland wordt een duidelijke relatie tussen arbeidsmarktomstandigheden en studiekeuze gevonden. Zie bijvoorbeeld Borghans, Heijke en De Grip (1996) voor een analyse van het keuzegedrag voor het Lager Technisch Onderwijs en Kodde (1985), Huijsman et al. (1986) en De Jong et al. (1998) voor de keuzemotieven bij het hoger onderwijs. Weerdenburg $(1985,1987)$ laat op basis van een enquête onder Nederlandse middelbaar scholieren zien dat arbeidsmarktoverwegingen voor een aanzienlijk deel van de scholieren meespelen bij de studiekeuze.

5. Wieling en Borghans (2001) laten zien dat het hierbij niet alleen om salaris gaat, maar ook talloze andere arbeidsvoorwaarden, zoals een vast contract, een rol spelen. 
weren dat studenten hierbij zeer rationeel te werk gaan en al rekening houden met de toekomstige ontwikkelingen op de arbeidsmarkt, terwijl Freeman (1985a,b) er van uit gaat dat studenten met hun studiekeuzes constant achter de feiten aanhobbelen. Interessant is om op te merken dat ook voor de keuze van huwelijkspartners op geaggregeerd niveau duidelijk patronen waarneembaar zijn. Fernandez en Rogerson (2001), Loughran (2002) en Gould en Paserman (2003) laten op verschillende wijze zien dat mensen een voorkeur hebben voor partners met een goed inkomen en men als de onzekerheid hierover toeneemt langer wacht met de huwelijksbeslissing.

Ondanks de grote invloed van toevalligheden lijken er voor het beleid dus terdege aangrijpingspunten te bestaan om de studie- en beroepskeuze te beïnvloeden. Dit roept de vraag op hoe die sterk persoonlijke studie- en beroepskeuze beïnvloedt wordt door het wervingsgedrag van de werkgevers, maar ook of de potentiële belangstelling voor een beroep optimaal wordt gemobiliseerd. De belangstelling voor een werkkring hangt af van de arbeidsvoorwaarden die daar worden geboden, maar ook van het beeld of imago dat de studie- of beroepskiezers daarvan hebben. Om goed te kunnen analyseren hoe deze keuzeprocessen kunnen worden beïnvloedt, moeten zowel de economische inzichten over de relatie tussen arbeidsmarktontwikkelingen en studiekeuze, als de psychologische kennis over de toevallige invloeden hierbij in ogenschouw worden genomen. ${ }^{6}$

In de standaard economische literatuur over studiekeuzes ${ }^{7}$ wordt vooral ingegaan op de relatie tussen arbeidsvoorwaarden en het aanbod van arbeid. Bij arbeidsvoorwaarden wordt verder primair gekeken naar het loon. In de psychologisch georiënteerde studie- en beroepskeuzeliteratuur staat het individuele ontwikkelingsperspectief centraal en wordt gekeken naar de manier waarop leerlingen zich een beeld vormen van beroepen en staat de vraag centraal hoe leerlingen geholpen kunnen worden een keuze te maken die zo goed mogelijk aansluit bij hun capaciteiten en interesses. ${ }^{8}$

Bij beleidsmatige afwegingen met betrekking tot dit keuzeproces spelen echter beide invalshoeken een rol en zijn zowel de feitelijke arbeidsvoorwaarden als de wijze waarop een leerling die percipieert bepalend voor de keuzes die worden gemaakt. Om er goed zicht op te krijgen hoe de individuele studie- en beroepskeuze samenhangt met de vraagontwikkelingen op de arbeidsmarkt wordt in dit hoofdstuk een raamwerk besproken waarin beide facetten worden geïntegreerd. Om duidelijk op een rij te krijgen welke factoren bepalend zijn voor het keuzeproces zal echter eerst de denkbeeldige situatie worden besproken waarin beeldvorming geen rol speelt, omdat leerlingen perfect geïnformeerd zijn over de aantrekkelijkheid van een baan

6. Zie Borghans (1999) voor een integratie van beide invalshoeken. Borghans en JacobTacken (2000) analyseren vanuit dit perspectief de beslissing om verpleegkunde te gaan studeren.

7. Deze invalshoek wordt aangeduid als de human capital theorie en is gebaseerd op het werk van Schultz (1963), Becker (1964) en Mincer (1974) Willes en Rosen (1979) analyseren specifiek de onderwijskeuzeproblematiek.

8. Met name de psychologen Parsons (1909), Ginzberg (1951), Rogers (1951), Super (1953, 1959) en Holland (1959) hebben hierop een grote invloed gehad. Zie Wiegersma (1990) voor een interessant overzicht van de ontwikkeling van het beroepskeuzewerk. 
en de feitelijk geboden arbeidsvoorwaarden. In een dergelijke situatie zijn de feitelijk geboden arbeidsvoorwaarden het enige instrument om de belangstelling voor een beroep te vergroten of te verkleinen. Vervolgens zal voortbouwend op dit "economisch model" worden besproken welke rol beeldvorming en imago spelen in dit proces. De centrale vraag die daar uit voortkomt is in hoeverre feitelijke arbeidsvoorwaarden en in hoeverre beeldvorming bepalend zijn voor de belangstelling bij studieen beroepskiezers.

\section{Volledige informatie}

Om een goed beeld te krijgen van de consequenties van studie- en beroepskeuzes die gebaseerd zijn op onvolledige beeldvorming en om na te kunnen gaan hoe beleidsmatig op een dergelijke situatie kan worden ingespeeld, zal in dit hoofdstuk eerst gekeken worden naar de interactie tussen vraag en aanbod als er wel volledige informatie zou zijn en dus studenten of werknemers precies kunnen overzien wat voor hen de voor- en nadelen van een bepaalde keuze zijn. In de praktijk wordt een dergelijke ideale situatie uiteraard nooit bereikt, maar deze hypothetische situatie van volledige informatie kan wel zeer goed functioneren als een ijkpunt voor de latere analyses waarin gekeken wordt naar de manier waarop beeldvorming het keuzeproces beïnvloedt.

\section{Figuur 1}

Relatie tussen beloning en keuze voor een opleiding

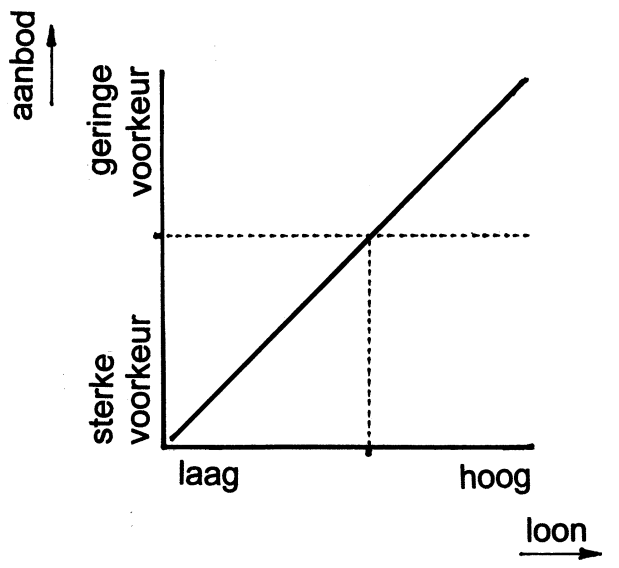

In figuur 1 wordt de arbeidsmarkt voor een specifiek beroep in beeld gebracht in dit het denkbeeldige geval van volledige informatie. Er wordt dus aangenomen dat leerlingen weten hoe aantrekkelijk dit beroep voor hen is, terwijl ze ook weten welke arbeidsvoorwaarden worden geboden. Er bestaan geen onduidelijkheden over de eigen capaciteiten en interesses en geen onduidelijkheden over wat het betekent om in dit beroep - piloot, vliegtuigmonteur, etc. - werkzaam te zijn. Om de grafiek 
overzichtelijk te houden wordt verder aangenomen dat de beloning de enige arbeidsvoorwaarde is die er toe doet. In de praktijk zal uiteraard een veelheid aan primaire en secondaire arbeidsvoorwaarden bepalend zijn voor de aantrekkelijkheid van een baan. Om de overwegingen op een rij te krijgen is deze nuancering op dit moment echter nog niet cruciaal.

Niet iedereen zal even graag in het betreffende beroep willen werken, omdat interesses en capaciteiten verschillen tussen individuen. Als iedereen een afweging maakt tussen de beloning die hij krijgt in een bepaalde functie en de inhoudelijke aantrekkelijkheid van die baan, dan zal als het loon stijgt een steeds grotere groep kiezen voor de betreffende baan. Voor iedereen kan het salaris waarbij men overstag gaat echter verschillen. Op de verticale as van de grafiek staan de potentiële werknemers gerangschikt op grond van dit drempelsalaris. Onderaan staat een persoon die erg graag in het betreffende luchtvaartberoep wil werken en dus een heel laag drempelsalaris heeft, terwijl boven aan de persoon staat die de luchtvaart zeer onaantrekkelijk vindt en dus een zeer hoge beloning moet ontvangen om de stap te willen zetten. Op de horizontale as staat het salaris en de lijn geeft aan bij welk salaris (op de horizontale as) een persoon (op de verticale as) net voldoende zal gaan verdienen om de keuze voor de sector voor hem aantrekkelijk te maken.

De feitelijke beloning die wordt geboden - zoals weergegeven op de horizontale as bepaalt in deze situatie volledig het aanbod van personeel. In deze eenvoudige situatie moet een werkgever dus als hij meer personeel aan wil trekken het salaris verhogen en kan hij als er te veel aanbod is het salaris omlaag doen. Andere mogelijkheden zijn er niet.

Figuur $2 a+b$

Relatie tussen de beloning en de keuze voor een opleiding als de voorkeuren van individuen sterk overeenkomen (figuur $2 a$ ) of sterk verschillen (figuur $2 b$ )
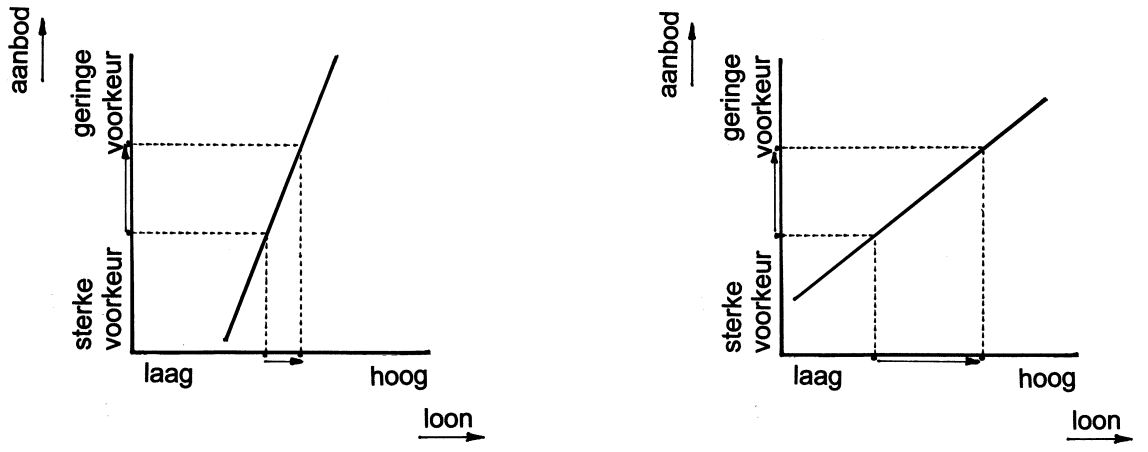

Figuur 2a

Figuur $2 b$

De manier waarop dit beloningsinstrument kan worden ingezet om meer personeel te werven zal overigens afhankelijk zijn van de omstandigheden. In de eerste plaats betekenen hogere salarissen voor een bedrijf ook hogere kosten. Bij een bedrijf dat 
ruime marges kent zal bij het aantrekken van extra mensen door het verhogen van het salaris daarom een afweging gemaakt moeten worden tussen deze extra salariskosten en de verminderde productie als men geen extra personeel aanneemt. Voor een bedrijf dat opereert in een sterk concurrerende markt, zullen de vrijheidsgraden echter beperkter zijn. Een kleine verhoging van de salariskosten zal hier immers snel tot gevolg hebben dat de productiekosten hoger worden dan de marktprijs. Als het werven van personeel moeilijker gaat dan verwacht, zullen de mogelijkheden om hier wat aan te doen beperkt zijn, en zal men deze knelpunten zeer nadrukkelijk ervaren.

Naast de mogelijkheid van het bedrijf om in te spelen op het aanbod, zal ook de mate waarin het aanbod reageert op de veranderingen in het salaris van geval tot geval verschillen. In figuur 2 wordt het verschil in beeld gebracht tussen een situatie waarin er weinig verschillen in voorkeur zijn binnen het potentiële aanbod (Figuur 2a) en de situatie waarin de voorkeuren voor het betreffende beroep sterk uiteen lopen (Figuur $2 b$ ). Als voor iedereen de interesse voor een beroep ongeveer gelijk is, zal ook het drempelloon dat men wil verdienen voor iedereen ongeveer gelijk zijn. Gevolg is dat een kleine verhoging van het salaris een enorme toename van de belangstelling tot gevolg heeft, maar ook dat een kleine verlaging van het salaris de belangstelling snel doet verminderen. Deze situatie waarbij er een sterke concurrentie is op de arbeidsmarkt zal zich voordoen als in de ogen van potentieel personeel de betreffende functies niet sterk verschillen van alternatieven die men elders heeft. De omgekeerde situatie (Figuur 2b) waarbij er grote verschillen bestaan in de voorkeur voor het betreffende beroep, heeft tot gevolg dat er grote salarisverhogingen nodig zijn om meer mensen te trekken, maar een kleine salarisverlaging weinig consequenties zal hebben. Deze situatie doet zich voor als het betreffende beroep qua inhoud sterk afwijkt van alternatieven die men heeft en het dus met name de inhoud van het werk en niet de arbeidsvoorwaarden zijn, die de doorslag geven bij de beroepskeuze. Het paradoxale van dit verschil tussen markten, met zoals economen dat noemen een hoge of een lage aanbodelasticiteit, is dat juist bij de markt waar de loonsconcurrentie het grootst is en mensen het sterkst reageren op kleine salarisverschillen, een betrekkelijk geringe salarisverhoging veel effect kan hebben. Als het salaris het enige instrument is om meer mensen te werven zal het juist op een markt waar mensen meer kiezen vanwege de inhoud en ze minder gevoelig zijn voor het salaris, duur zijn om het aanbod substantieel te vergroten.

\section{Knelpunten in de personeelswerving}

In kringen van personeelsfunctionarissen en in de media wordt vaak gesproken over knelpunten bij de personeelsvoorziening. Hiermee worden omstandigheden bedoeld waarbij het moeilijk is om een bepaalde categorie personeel te werven. Vanuit het hierboven geschetste perspectief is het niet vanzelfsprekend wat bedoeld wordt met knelpunten in de personeelswerving. Impliciet wordt vaak aangenomen dat het aantal beschikbare mensen een vast gegeven is en dat het aanbod van personeel niet gestuurd kan worden met een verandering in de arbeidsvoorwaarden. Gegeven een bepaald loon leidt in een dergelijke visie iedere toename van de vraag en iedere 
afname van het aanbod tot knelpunten in de personeelsvoorziening. In werkelijkheid kunnen en zullen bedrijven echter reageren op deze dreigende tekorten door voor dezelfde functie meer te gaan bieden. Dit zal echter niet altijd makkelijk zijn. Hogere lonen betekenen immers hogere kosten en dus een lagere winst. Men kan daarom knelpunten in de personeelsvoorziening beter zien als verschuivingen in vraag of aanbod in relatie met de mogelijkheden die er zijn om de arbeidsvoorwaarden hierop aan te passen. Voor bedrijven met grote winstmarges of voor bedrijven waarvoor de personeelskosten een relatief kleine fractie zijn van de totale kosten zal het eenvoudiger zijn om de arbeidsvoorwaarden waar nodig aan te passen dan voor bedrijven waarvoor de marges klein zijn. Bij die laatste bedrijven zal een afname van het aanbod van personeel dan ook eerder als een knelpunt worden ervaren. Dus ook als de vraag naar personeel toeneemt omdat de winstgevendheid van de bedrijfsactiviteit is gestegen, zal het relatief eenvoudig zijn de werving van personeel aan te passen aan de nieuwe omstandigheden. Als echter het aanbod van personeel afneemt omdat andere bedrijfstakken winstgevender zijn geworden en dezelfde groepen personeel meer zijn gaan bieden, dan zal de ruimte voor een bedrijf om hierin mee te gaan, beperkt zijn, en zullen de ontwikkelingen eerder als knelpunt worden gevoeld.

\section{Onzekerheid bij de keuze}

Totnogtoe is aangenomen dat mensen precies weten hoe aantrekkelijk een bepaalde functie voor hen is. In werkelijkheid zal het niet zo zijn dat men volledig beseft wat de voor- en nadelen van een bepaalde functie zijn en men de arbeidsvoorwaarden in verschillende functies heel nauwgezet tegen elkaar afweegt. De keuze wordt niet gebaseerd op de feitelijke situatie, maar op het beeld of imago dat men heeft van het betreffende beroep. De relatie tussen arbeidsvoorwaarden en de keuze die men maakt is dan ook niet meer één op één, maar er ontstaat een toevalselement dat afhangt van de wijze waarop de betrokkene zich een beeld van het beroep heeft gevormd. Figuur 3 laat zien wat er gebeurt als er onzekerheid in het keuzeproces wordt geïntroduceerd. Personen worden nu niet meer weergegeven door punten op één lijn, maar liggen verspreid over het hele vlak. Op de horizontale as wordt de werkelijke voorkeur van mensen aangegeven op basis van het loon dat zij minstens zouden moeten verdienen om deze baan aantrekkelijker te vinden dan alternatieven. Op de verticale as wordt aangegeven hoe ze op basis van onvolledige informatie deze aantrekkelijk te hoog of te laag inschatten. Mensen met een positief beeld van de opleiding staan weer laag op de as, mensen die denken dat de opleiding niets voor hen is staan bovenaan. Doordat ook de werkelijke voorkeur - dat is de denkbeeldige voorkeur die men zou hebben als men alle aspecten en consequenties van de keuze zou doorzien - in de grafiek te zien is, kan worden afgelezen of iemand te optimistisch of te pessimistisch is over de studie of het beroep dat wordt bekeken. ledereen die precies op de lijn ligt heeft realistische inschattingen over de keuze waar hij voor staat. Ligt men onder de lijn, dan is men te optimistisch en ligt men boven de lijn dan is men te pessimistisch. 
Figuur 3

Relatie tussen beloning en de keuze voor een opleiding als er onzekerheid is voor de eigen voorkeur

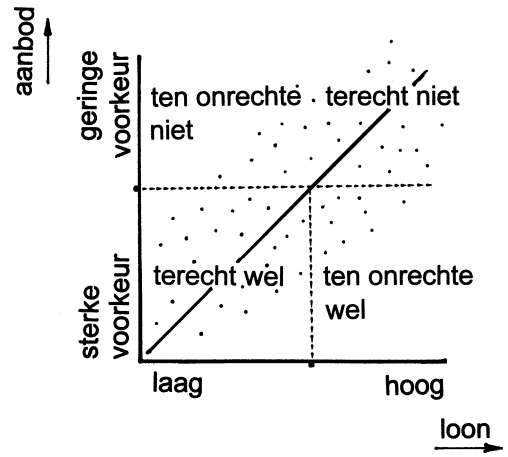

In figuur 3 wordt een situatie weergegeven waarin evenveel optimisten als pessimisten voorkomen. Mensen hebben dus geen perfect beeld van de keuze, maar de kans dat ze de situatie te gunstig zien is even groot als de kans dat men de mogelijke keuze te ongunstig inschat. Gegeven een bepaald loon zal iedereen die onder de horizontale stippellijn is getekend, besluiten voor het betreffende vak te kiezen. Doordat mensen in dit voorbeeld gemiddeld genomen een juiste inschatting maken, zal het totale aanbod niet anders zijn dan in het geval van perfecte informatie. Toch is er echter een belangrijk verschil. In de groep die nu kiest voor de betreffende baan, is ook een groep die dit eigenlijk niet had willen doen. In de figuur is deze groep aangegeven met "ten onrechte wel". Het ligt voor de hand om te verwachten dat als deze mensen eenmaal zijn opgeleid en in het beroep gaan werken, ze een veel realistischer beeld krijgen van het vak waarvoor ze hebben gekozen. Men zal er daarom alsnog achter komen dat men eigenlijk een verkeerde keuze heeft gemaakt en spijt heeft van de keuze. In een aantal gevallen zal men de eenmaal ingeslagen weg niet meer verlaten, maar wel minder tevreden zijn over de loopbaan dan men anders zou zijn geweest. Anderen zullen echter besluiten om de studie- of beroepskeuze te herzien en al dan niet na herscholing in een ander vak gaan werken. Een deel van het aanbod zal daarom mogelijk alsnog verloren gaan. Tegenover deze groep mensen die ten onrechte wel voor dit beroep heeft gekozen, staat een groep van gelijke omvang die ten onrechte niet hiervoor gekozen heeft. Als het mogelijk zou zijn om door het geven van betere informatie deze groep te werven en de groep die ten onrechte wel voor dit beroep gekozen heeft duidelijk te maken dat andere mogelijkheden voor hen aantrekkelijker zijn, dan zou het aanbod van personeel bestaan uit een groep die veel meer past bij de functie en daardoor waarschijnlijk ook veel sterker gemotiveerd zal zijn.

De beelden over een bepaald beroep die mensen hebben staan echter niet los van elkaar. Hoewel er altijd grote individuele verschillen in de perceptie zullen bestaan, gaat het er bij de problematiek van onjuiste beeldvorming juist om dat mensen in zijn algemeenheid een te gunstig of een te ongunstig beeld van een beroep hebben. 
Figuur 4 laat een dergelijke situatie zien waarin er stelselmatig een te slecht imago van een beroep bestaat. Doordat in dit voorbeeld mensen gemiddeld te negatief denken over werken in dit beroep is de groep die ten onrechte niet voor dit beroep kiest veel groter dan de groep die ten onrechte wel hiervoor kiest. Om in een dergelijke situatie toch voldoende personeel te krijgen zijn er twee mogelijkheden. De eerste mogelijkheid is om de beloning te verhogen. Ondanks een slecht imago zal bij een toenemende beloning de groep die wel voor dit beroep kiest steeds groter worden. De tweede mogelijkheid is om het imago te verbeteren en maatregelen te nemen waardoor beeld en werkelijkheid dichter bij elkaar komen te staan.

Figuur 4

De relatie tussen beloning en de keuze voor een opleiding als mensen gemiddeld genomen een te ongunstig beeld van de opleiding hebben

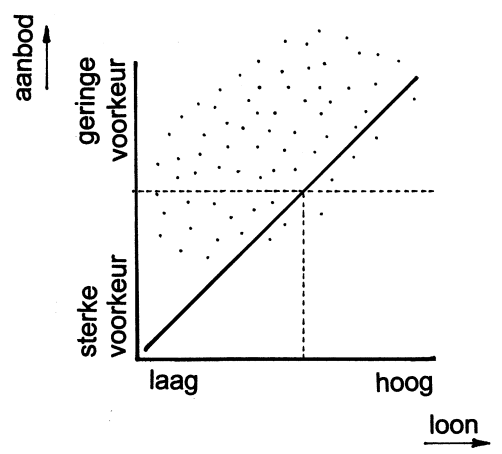

Overigens kan een imago ook gunstiger zijn dan de werkelijkheid en dus zou men ook als er geen imagoproblemen zijn kunnen proberen om de belangstelling voor een beroep te vergroten door te werken aan een imago dat gunstiger is dan de feitelijke situatie. Een dergelijk beleid kent twee beperkingen. Ten eerste is het de vraag of het mogelijk zal zijn bewust een imago te creëren dat gunstiger is dan de werkelijkheid. Mensen zullen immer langs verschillende wegen tot een beeld van een beroep komen. Als het beeld dat uit voorlichtingsmateriaal naar voren komt voelbaar te positief is, of als er grote discrepanties bestaan tussen dit voorlichtingsmateriaal en wat mensen te horen krijgen van familie of bekenden die in de sector werken, zal de geloofwaardigheid en daarmee de invloed van dit materiaal minder worden. Een tweede beperking is dat als het imago te gunstig is, er een relatief grote groep is die kiest voor een vak, maar hier achteraf gezien niet tevreden mee is. Hoewel in dat geval gegeven de geboden arbeidsvoorwaarden veel aanbod wordt binnengehaald, zal ook dit nadelen kennen, omdat de betrokken werknemers ontevreden zijn en wellicht ook snel weer elders werk zullen zoeken. 
Een belangrijke vraag die hierbij opkomt is of de studie- en beroepskeuze wel te beïnvloeden is met voorlichting of een imagocampagne. Hierboven werd al aangegeven dat studie- en beroepskeuzes op geaggregeerd niveau duidelijk samen blijken te hangen met de beloning en andere arbeidsvoorwaarden in een beroep. De vraag die hier aan de orde is, is echter of men gegeven deze beloning ook kan bevorderen dat bij individuele keuzes de percepties dichter bij de werkelijkheid staan en dus minder mensen een onterechte studie- of beroepskeuze maken. Silbereisen, Vondraeck en Berg (1997) laten zien dat de tijdsbesteding tijdens de jeugd een belangrijke bijdrage levert aan de vorming van adequate beroepsbeelden. Jongeren die veel tijd doorbrengen met de familie of tijd besteden voor zelfontwikkeling vormen een adequater beroepsbeeld dan jongeren die veel tijd besteden aan omgang met vrienden of culturele activiteiten. Borghans en Jacob-Tacken (2000) analyseren het keuzeproces bij verpleegkundigen en concluderen dat leerlingen die een familielid of goede bekende hebben die in de zorgsector werkzaam is, op zich niet sneller voor de zorg kiezen, maar als zij dat doen wel minder vaak teleurgesteld zijn in deze keuze. Er zijn duidelijk aanwijzingen dat vroegtijdige contacten met de beroepswereld de beste garantie zijn voor een adequate beroepsbeeldvorming. Boreham en Arthur (1993) constateren dat contact met de werkwereld bevorderlijk is voor het keuzeproces, maar laten ook zien dat deze contacten bij jongeren die hun beroepsopleiding nog moeten kiezen nog nauwelijks aanwezig zijn. De vraag is dus hoe men kan bewerkstelligen dat de ontwikkeling van een dergelijk beroepsbeeld niet afhangt van de toevallige familie en kennissenkring.

Whan Marko en Savickas (1998) onderzochten of men het beroepskeuzeproces kan verbeteren met een "career time perspective intervention", een vijf weken durende cursus waarin nadenken over de latere loopbaan centraal staat. Het bleek dat leerlingen die deze cursus volgden zich wel bewuster waren van het belang van studie- en beroepskeuzes, maar dit leidde niet tot adequatere keuzes. Alleen nadenken over de studie- en beroepskeuze is dus niet voldoende. Een aantal auteurs (Kablaoui en Pautler, 1991, Lewis, Gardner en Seita, 1983, D'Amico, 1983, Meyer en Wise, 1980, Lewin-Epstein, 1981 en Stephenson, 1980) hebben daarom onderzocht of bijbaantjes bij scholieren zorgdragen voor een beter beroepsbeeldvorming. Steeds blijkt het effect hiervan gering te zijn. De reden hiervoor is dat de typische bijbaantjes van jongeren weinig te maken hebben met de latere beroepen waarin men terecht zal komen. Veel lijkt er dus op te wijzen dat men jongeren ruim voor zij belangrijke studiekeuzes moeten maken in contact moet laten komen met in dit geval de lucht- en ruimtevaart en men hen moet laten ervaren hoe het werkelijk is om in deze sector te werken. Greenberger en Steinberg (1986) en Hotchkiss (1986) laten zien dat bijbaantjes tijdens de studie bijdragen aan de kennis over hoe het er aan toe gaat op het werk, maar het betreft hier leerlingen die al voor een bepaalde beroepsopleiding hebben gekozen, zodat er geen effect op de beroepskeuze meer te verwachten valt. Nishida (1992) laat voor Japanse leerlingen zien dat gerichte werkervaring de kwaliteit van het studie- en beroepskeuzeproces kan bevorderen. 
Het doel van dit rapport is om inzicht te krijgen in de vraag hoe de belangstelling voor de lucht- en ruimtevaart gestimuleerd kan worden. Vanuit het hierboven beschreven perspectief is het daartoe allereerst van belang om na te gaan in hoeverre een bepaald beroep binnen de lucht- en ruimtevaart gezien moet worden als een afzonderlijk arbeidsmarktsegment, of dat het deel uit maakt van een groter arbeidsmarktsegment, waarbij het de betrokkenen weinig uitmaakt of men in de lucht- en ruimtevaart of in een andere sector werkzaam is. Als de lucht- en ruimtevaart voor een bepaald beroep slechts een klein onderdeel is van een grotere arbeidsmarkt, dan zal aan de ene kant de concurrentie om het personeel groter zijn. Kleine verschillen in arbeidsvoorwaarden of imago kunnen betekenen dat werknemers in grote getale voor andere sectoren kiezen. Aan de andere kant betekent zo'n grote markt ook dat er altijd een omvangrijk reservoir is aan potentieel personeel. Een kleine verbetering van de arbeidsvoorwaarden kan een sterke invloed hebben op het aanbod.

Een cruciale vraag die personeelsfunctionarissen zich moeten stellen als ze het aanbod aan personeel willen vergroten is of het imago van het beroep tekort schiet en verbeterd moet worden, of dat het nodig zal zijn de arbeidsvoorwaarden te verbeteren. Als mensen immers goed geïnformeerd zijn over de voor- en nadelen van een beroep valt niet te verwachten dat door het geven van informatie over dit beroep de keuze kan worden beïnvloedt. In dit rapport bekijken we daarom hoe schoolverlaters terugblikken op hun studiekeuze. Zegt men achteraf dat de men als men opnieuw voor de keuze stond, dezelfde opleiding zou kiezen, dan is kennelijk de gemaakte keuze niet beïnvloedt door een verkeerd beeld. Als men wel spijt zegt te hebben van de studiekeuze, dan is er kennelijk wel sprake van een discrepantie tussen verwachting over het beroep toen men voor de studiekeuze stond, en de werkelijkheid die men na afloop van de opleiding aantreft.

Het kan overigens ook zo zijn dat men gemiddeld genomen wel een juist beeld heeft van een opleiding of beroep, maar dat aan de ene kant een grote groep bestaat die een te gunstig beeld heeft, terwijl daar een groep tegenover staat die een te negatief beeld heeft van de opleiding. De consequentie hiervan is dat er een potentieel van geïnteresseerde werknemers niet wordt benut, terwijl een groep mensen die wel in dit beroep is komen werken achteraf gezien ontevreden is met de gemaakte keuze. Een dergelijke situatie zal zich met name voordoen als de keuze voor een bepaald beroep een sterk persoonlijke afweging is en dus meer de inhoudelijke aspecten van het werk dan het salaris bepalend zijn voor de beroepskeuze.

Analyses van studiekeuzegedrag of van personeelsbeleid zijn meestal gebaseerd op (1) een inventarisatie van de verschillen tussen degenen die wel en degenen die niet voor een bepaalde opleiding of beroep hebben gekozen, of (2) klachten van personen die voor deze opleiding of dit beroep hebben gekozen maar ontevreden zijn (bijvoorbeeld exit-interviews). Het schema maakt echter duidelijk dat informatie over deze groep weinig houvast biedt voor een verbeterd personeelsbeleid. Als men optimaal gebruik wil maken van de potentiële belangstelling voor een beroep, dan 
moet het beleid er immers niet op gericht zijn om de functie aantrekkelijker te maken voor degenen die eigenlijk iets anders hadden moeten kiezen, maar dan zal men zich in de eerste plaats moeten richten op degenen die in principe wel belangstelling hebben, maar door onduidelijke informatievoorziening toch niet op de juiste plek terecht zijn gekomen. Gezien de onvoorspelbaarheid van individuele studiekeuzes ligt het niet voor de hand om op zoek te gaan naar de kenmerken van degenen die passen bij een bepaald beroep. De voorspellende waarde daarvan zou gering zijn en bovendien is het nog maar de vraag of potentiële studiekiezers zich door dergelijke informatie laten overtuigen dat ze de "verkeerde" studiekeuze dreigen te maken. Om werkelijk het studiekeuzeproces positief te beïnvloeden zal bekeken moeten worden waarom sommige leerlingen vooraf al weten dat een bepaald beroep wat voor hen is of niet, terwijl anderen keuzen maken waarvan ze achteraf spijt krijgen. Als duidelijk wordt welke informatie of ervaring tot adequate inzichten over de latere beroepsuitoefening heeft geleid, ongeacht de vraag of men uiteindelijk wel of niet voor dat beroep heeft gekozen, dan biedt dat de beste aanknopingspunten voor een imago- of voorlichtingsbeleid. 



\section{Werkgelegenheid in de cluster}

De belangrijkste statistische bron in Nederland, om een beeld te krijgen van de samenstelling van de beroepsbevolking naar beroep, bedrijfssector en opleidingsachtergrond is de Enquête Beroepsbevolking (EBB). In deze enquête wordt een zeer grote steekproef van de Nederlandse bevolking ondervraagd ( $1 \%$ van de Nederlandse bevolking). Het Centraal Bureau voor de Statistiek verzamelt daarnaast ook rechtstreeks bij bedrijven gegevens over het aantal werknemers dat men in dienst heeft (Enquête Werkgelegenheid en Lonen, EWL). Op grond hiervan kan men de statistische onzekerheid van de Enquête Beroepsbevolking reduceren door de resultaten te herwegen, zodanig dat de aantallen personen per bedrijfssector in de Enquête overeenkomen met andere telgegevens.

Hoewel de cijfers uit de EBB dus overeen moeten komen met gegevens zoals die bij bedrijven bekend zijn, blijken zich er toch vaak voor het gevoel discrepanties voor te doen. Dit heeft een aantal oorzaken. In de eerste plaats definieert het CBS de beroepsbevolking als de bevolking die in Nederland woont en minstens 12 uur per week werkt. Werknemers bij Nederlandse bedrijven die niet in Nederland wonen ook al is de bedrijfsvestiging wel in Nederland - worden dus niet meegenomen. Verder vallen banen van minder dan 12 uur buiten de categorie van het CBS. Een belangrijkere discrepantie ontstaat echter bij het vaststellen van de bedrijfssector. Voor het CBS hoort een bedrijf of bedrijfsonderdeel tot een bepaalde (deel)sector als dit bedrijf(sonderdeel) hoofdzakelijk bepaalde activiteiten uitvoert (bijvoorbeeld het maken van vliegtuigonderdelen) en ook qua beschikbaar kapitaal en personeel in eerste instantie alleen deze activiteiten uit kan voeren. Dit betekent dat een bedrijf dat alleen vloerbedekkingen maakt voor vliegtuigen, waarschijnlijk niet tot de vliegtuigbouw wordt gerekend, omdat men gezien de machines die men heeft en het personeel waar men over beschikt makkelijk ook vloerbedekkingen voor andere toepassingen kan maken. In de ogen van het CBS is dan de vliegtuigindustrie (toevallig) de enige afnemer van dit product en is het bedrijf in haar klantenkring, maar niet in het productieproces dus sterk verbonden aan de vliegtuigindustrie. Ook een bedrijfsonderdeel dat de ene keer deuren voor vliegtuigen maakt maar een andere keer een opdracht aanneemt om deuren voor treinen te maken wordt ingedeeld in een algemenere categorie dan de vliegtuigbouw. Deze afweging wordt afzonderlijk gemaakt voor alle bedrijfsonderdelen die bij de dagelijkse bedrijfsuitvoering zelfstandig opereren. Het feit dat men deel uitmaakt van een groter geheel is hierbij dus niet van invloed. De concrete indeling van bedrijven over bedrijfssectoren wordt gemaakt door het CBS en wordt neergelegd in het zogenaamde bedrijfsregister. Het is echter niet mogelijk om inzage in dit bedrijfsregister te krijgen, omdat het CBS wil voorkomen dat individuele bedrijven te makkelijk te herkennen zijn in de gegevens van databestanden zoals de EBB.

In tabel 3.1 wordt een beeld gegeven van de omvang van het Lucht- en Ruimtevaartcluster. Gegevens uit de EBB kunnen niet zonder meer gepubliceerd worden. Het CBS is van mening dat cijfers die betrekking hebben op minder dan 10.000 personen een te grote onbetrouwbaarheid hebben om te kunnen worden gepubliceerd. Om die 
reden is in tabel 3.1 voor de kleinere onderdelen een schatting gemaakt van het aantal werkenden in 2000 , op basis van de ontwikkeling in de cijfers over de periode 1996-2000. Hierdoor worden toevallige jaarlijkse fluctuaties weggefilterd. Deze gehele reeks in ogenschouw nemend, kan men echter constateren dat deze schatting vrij nauwkeurig is.

Binnen de indeling van het CBS is het mogelijk om vier onderdelen binnen het luchten ruimtevaartcluster te onderscheiden: Vervaardiging van vliegtuigen en vliegtuigonderdelen (incl. onderhoud); Vervoer door de lucht; Luchthavens en Verhuur van vliegtuigen. In dit rapport zullen we de eerste deelsectoren aanduiden als "vliegtuigbouw". Vervoer door de lucht en luchthavens worden soms samengenomen onder de noemer "luchtvaart". Defensie is als één categorie in de statistieken terug te vinden waardoor het niet mogelijk is om op basis van de EBB afzonderlijke gegevens voor de luchtmacht te presenteren.

De tabel laat zien dat de luchtvaartmaatschappijen verreweg het grootste deel van de werkgelegenheid in de cluster voor hun rekening nemen. De aantallen werkenden bij de vliegtuigbouw, zoals die in de EBB naar voren komen, zijn overigens aanmerkelijk lager dan de cijfers die de AECMA over de vliegtuigbouwsector in Nederland presenteert. ${ }^{9}$ Voor 2000 raamt deze organisatie van de Europese luchtvaartindustrie de werkgelegenheid in Nederland op 11.300 mensen. Dit verschil wordt waarschijnlijk verklaard doordat de AECMA sneller dan het CBS bedrijven tot deze sector rekent. De striktere definitie die het CBS hanteert heeft als voordeel dat de focus ligt op activiteiten die zeer typisch zijn voor de vliegtuigindustrie. Bedrijven die veel werk verrichten voor de lucht- en ruimtevaartsector, maar hierbij mensen in dienst hebben die qua kennis en ervaring ook voor andere sectoren kunnen werken zullen immers ook minder last hebben van specifieke problemen op de arbeidsmarkt voor de lucht- en ruimtevaart.

\section{Tabel 3.1}

Aantal werkenden in 2000 bij een viertal onderdelen van de lucht- en ruimtevaart (schatting op basis van de EBB)

\begin{tabular}{lcc}
\hline & Aantal werkenden in 2000 & $\begin{array}{c}\text { Gemiddelde jaarlijkse groei } \\
1996-2000 \\
\%\end{array}$ \\
& & \\
& & $-6,3$ \\
Vliegtuigbouw & 5.200 & $-0,6$ \\
Vervoer door de lucht & 31.400 & $-2,7$ \\
Luchthavens & 3.500 & - \\
Verhuur vliegtuigen & 900 & - \\
Luchtmacht & - & \\
& & \\
\hline
\end{tabular}

De werkgelegenheid bij de vervaardiging van vliegtuigen is overigens sterk teruggelopen na het faillissement van Fokker. Om die reden is in de tabel dan ook

9. Zie AECMA (2001). 
een fors negatieve jaarlijkse groei terug te vinden. Deze krimp heeft zich hoofdzakelijk vlak na 1996 voorgedaan.

Voor een analyse van de arbeidsmarkt voor de lucht- en ruimtevaart is overigens het absolute aantal werkenden niet van primair belang. Veel belangrijk is de relatieve samenstelling van de werkgelegenheid. In tabel 3.2 wordt een beeld gegeven van de opbouw van het personeel naar opleidingsniveau. Ter vergelijking zijn ook de verdelingscijfers van de gehele Nederlandse beroepsbevolking opgenomen.

Uit de tabel komt naar voren dat met name bij de luchthavens relatief veel ongediplomeerden (basisonderwijs) werkzaam zijn. Bij de vliegtuigbouw en vervoer door de lucht werken relatief gezien minder ongediplomeerden dan op de Nederlandse arbeidsmarkt in zijn geheel. Bij de luchtvaartmaatschappijen werken opvallend veel mensen met een mavo-, havo-, of vwo-diploma. De vliegtuigbouw is daarentegen, zeker in vergelijking met de andere onderscheiden luchtvaartsectoren, een typische afnemer van MBO'ers. Dit percentage ligt overigens niet veel hoger dan het landelijke gemiddelde en is bovendien de laatste jaren fors aan het dalen. Zowel bij vervoer door de lucht als bij de luchthavens werken veel meer HBO'ers dan het landelijke gemiddelde. Bij de luchthavens is dit aandeel bovendien duidelijk aan het stijgen. Het aandeel WO'ers is bij alle drie de deelsectoren iets hoger dan het landelijke gemiddelde. Bij de vliegtuigbouw stijgt het aantal academici de laatste tijd veel harder dan de landelijke groei van academici op de arbeidsmarkt.

Tabel 3.2

Relatieve werkgelegenheid van mensen binnen de lucht- en ruimtevaart in 2000 en een indicatie van sterke verschuivingen in de periode 1996-2000 (schatting op basis van de EBB)

\begin{tabular}{|c|c|c|c|c|}
\hline & $\begin{array}{c}\text { Bouw } \\
\%\end{array}$ & $\begin{array}{c}\text { Vervoer door de } \\
\text { lucht } \\
\%\end{array}$ & $\begin{array}{c}\text { Luchthavens } \\
\%\end{array}$ & $\begin{array}{c}\text { Nederland } \\
\%\end{array}$ \\
\hline Basisonderwijs & 6 & 4 & 14 & 8 \\
\hline $\begin{array}{l}\text { Mavo, havo, } \\
\text { vwo }\end{array}$ & 6 & 21 & $9(-)$ & 12 \\
\hline VMBO & $8(-)$ & 7 & 6 & 13 \\
\hline MBO & $42(-)$ & 31 & $20(-)$ & 37 \\
\hline $\mathrm{HBO}$ & 12 & 29 & $37(+)$ & 19 \\
\hline WO & $13(+)$ & 10 & 14 & 11 \\
\hline Totaal & 100 & 100 & 100 & 100 \\
\hline
\end{tabular}





\section{De marktpositie van de Nederlandse lucht- en ruimtevaart}

De afbakening die in het voorgaande hoofdstuk is gemaakt, is vooral gebaseerd op het product van het bedrijf of bedrijfsonderdeel waar mensen werken. Als er vliegtuigonderdelen worden gemaakt of onderhouden, of als bij een organisatie wordt gewerkt aan het vliegverkeer, wordt deze gerekend tot het lucht- en ruimtevaartcluster. Vanuit arbeidsmarktoptiek betekent dit echter niet dat de mensen die bij deze bedrijven werken allemaal in hetzelfde schuitje zitten. Veel functies die bij een vliegtuigproducent of bij een luchtvaartmaatschappij worden uitgeoefend zijn ook terug te vinden bij totaal andere bedrijven. Het kan dus het geval zijn dat het een deel van de personeelsleden niet zo veel uitmaakt of ze werken bij een bedrijf in het lucht- en ruimtevaartcluster of dat ze binnen een totaal andere bedrijfssector werkzaam zijn. Voor het kantinepersoneel of een secretaresse is dit onmiddellijk duidelijk. Echter ook voor technisch personeel is niet uit te sluiten dat in de perceptie van de betrokkenen weinig verschil bestaat tussen het werk dat men bij een vliegtuigbouwer of bij een autoproducent verricht.

Als in de perceptie van werknemers weinig verschil bestaat tussen de werkzaamheden in het lucht- en ruimtevaartcluster en vergelijkbaar werk in andere sectoren dan is er niet echt sprake van een specifieke arbeidsmarkt voor deze sector. Problemen die de arbeidsmarkt als geheel voor bijvoorbeeld secretaresses ondervindt, zullen dan ook de problemen voor de lucht- en ruimtevaartbedrijven vormen. Naarmate de lucht- en ruimtevaart voor bepaalde functies meer opereert in een bredere arbeidsmarkt en geen afzonderlijk segment op de markt vormt, treden er, zoals we in hoofdstuk 2 hebben laten zien, twee effecten op. Ten eerste, zal een toename of een afname in de vraag naar deze mensen worden geabsorbeerd door een veel grotere markt, waardoor deze schommelingen in de vraag minder gevoeld zullen worden door de sector zelf. Ten tweede zal echter, als de bedrijven in de cluster sterker afhankelijk zijn van een groter segment van de arbeidsmarkt, de concurrentie ook veel sterker zijn. Als het werknemers inhoudelijk niet uitmaakt of ze bij een bedrijf binnen of buiten de lucht- en ruimtevaart werken, dan kunnen kleine verschillen in beloning, reisafstand, secondaire arbeidsvoorwaarden etc. betekenen dat mensen met groot gemak elders werk zullen aanvaarden. Binnen zo'n gezamenlijke arbeidsmarkt zal ook de lucht- en ruimtevaart de beloning van het werk aan moeten passen als buiten de eigen cluster de productiviteit toe gaat nemen. Dergelijke ontwikkelingen kunnen, zoals ook in hoofdstuk 2 is besproken makkelijk leiden tot spanningen tussen de kosten die gemaakt moeten worden voor personeel en de opbrengst van de bedrijfsvoering. Als men de beloning niet aanpast aan de ontwikkelingen op de arbeidsmarkt zullen er problemen in de personeelswerving ontstaan. Als men de personeelskosten niet in toom weet te houden zullen er problemen op de afzetmarkt ontstaan.

Er zijn twee invalshoeken die bepalend zijn voor de vraag of er binnen de lucht- en ruimtevaart, voor bepaalde groepen, sprake is van een afgebakend arbeidsmarkt- 
segment. Deze twee invalshoeken zijn de aard van de werkzaamheden en omstandigheden waaronder die werkzaamheden uitgeoefend moeten worden. Op beide invalshoeken zal hieronder worden ingegaan.

\section{Aard van de werkzaamheden}

In tabel 4.1 wordt in beeld gebracht welke beroepen relatief belangrijk zijn voor de lucht- en ruimtevaart. Omdat ook op de Nederlandse arbeidsmarkt in het geheel sommige beroepen meer voorkomen dan andere is ook de verdeling voor de hele arbeidsmarkt opgenomen. De eerste kolom geeft aan welk aandeel de onderscheiden beroepsgroepen en beroepen hebben in de totale werkgelegenheid in de cluster. Stewardessen vormen het omvangrijkste beroep. Echter ook de technici en piloten vormen een substantieel aandeel van de werkgelegenheid. De tweede kolom geeft aan hoe de werkgelegenheid in Nederlands verdeeld is over de onderscheiden beroepen. Technici vormen ook voor de gehele Nederlandse arbeidsmarkt een omvangrijke groep, maar de stewardessen en piloten zijn als fractie van de gehele Nederlandse beroepsbevolking vrij onbeduidend. In de derde kolom wordt aangegeven hoeveel procent van de werkgelegenheid in de betreffende beroepen werkzaam is in het lucht- en ruimtevaartcluster. Voor de totale Nederlandse beroepsbevolking neemt de lucht- en ruimtevaart $0,58 \%$ in. Als in deze kolom bij een beroep een percentage staat dat hoger is dan $0,58 \%$ dan is dit beroep in de lucht- en ruimtevaart dus relatief oververtegenwoordigd in vergelijking met de gehele Nederlandse arbeidsmarkt.

\section{Tabel 4.1}

Aandeel van verschillende beroepen in de werkgelegenheid van de lucht- en ruimtevaart en de Nederlandse arbeidsmarkt als geheel, en het aandeel van de lucht- en ruimtevaart in de totale Nederlandse werkgelegenheid in dat beroep

\begin{tabular}{lccc}
\hline $\begin{array}{l}\text { Beroepsgroep } \\
\text { Beroep }\end{array}$ & $\begin{array}{c}\text { Percentage van } \\
\text { werkgelegenheid } \\
\text { in cluster }\end{array}$ & $\begin{array}{c}\text { Percentage van } \\
\text { werkgelegenheid } \\
\text { in Nederland }\end{array}$ & $\begin{array}{c}\text { Aandeel } \\
\text { werkgelegenheid } \\
\text { lucht- en } \\
\text { ruimtevaart t.o.v. } \\
\text { Nederland } \\
\%\end{array}$ \\
& & & $\begin{array}{c}\% \\
\text { Elementaire beroepen }\end{array}$ \\
$\quad$ waarvan sjouwers & 8,73 & 6,73 & 0,75 \\
$\begin{array}{l}\text { Ondersteunende adm. hulpkrachten } \\
\text { Middelbaar technische beroepen }\end{array}$ & 2,49 & 0,30 & 4,85 \\
$\quad$ waarvan auto/vliegtuigelektricien & 10,25 & 0,08 & 1,92 \\
Middelbare transportberoepen & 1,50 & 10,30 & 0,62 \\
$\quad$ waarvan steward(ess) & 26,68 & 0,03 & 31,58 \\
$\quad$ waarvan grondsteward(ess) & 19,70 & 0,87 & 17,69 \\
Economen en informatici & 2,99 & 0,11 & 80,0 \\
Piloten, kapiteins en leidinggeven- & 0,75 & 0,02 & 2,36 \\
den transport & 13,47 & 0,18 & 33,96 \\
$\quad$ waarvan piloot & 9,98 & 0,23 & 97,56 \\
Totaal & 100 & 0,06 & 0,58 \\
\hline
\end{tabular}


Het valt op dat er in het lucht- en ruimtevaartcluster slechts enkele beroepen zijn die zeer specifiek zijn voor deze sector. Het gaat hier om vliegtuigtechnici, stewardessen en piloten. Bij de beroepsindeling van het CBS worden verschillende technische specialisaties samengenomen in één beroep. Het is echter mogelijk dat in werkelijkheid deze verschillende specialisten minder makkelijk van de ene naar de andere sector overgaan dan door deze indeling wordt gesuggereerd. Zeker voor werknemers die reeds enige tijd werkzaam zijn kan de rol van sectorspecifieke kennis belangrijk zijn. Met name voor de technici valt daardoor moeilijk te bepalen hoe specifiek het werk in de lucht- en ruimtevaart is in vergelijking met het werk dat deze werknemers elders kunnen doen. Als men echter aanneemt dat ook de technici in de lucht- en ruimtevaart tot een specifiek segment moeten worden gerekend dan is in totaliteit ongeveer $40 \%$ van de werkgelegenheid (technici, stewardessen en piloten) specifieke voor de cluster. Voor de overige $60 \%$ werft de lucht- en ruimtevaart dus arbeidskrachten die werkzaamheden verrichten die ook in veel andere sectoren vaak terug te vinden zijn. Op grond van de aard van de werkzaamheden valt niet te verwachten dat de lucht- en ruimtevaart voor deze groep specifieke wervingsproblemen zal hebben.

\section{Arbeidsomstandigheden}

Naast verschillen in de aard van het werk kunnen er echter ook verschillen zijn in de omstandigheden waaronder het werk wordt uitgevoerd. Als het werk in de lucht- en ruimtevaart duidelijk andere arbeidsomstandigheden kent dan vergelijkbaar werk in andere sectoren dan kan dit een rol spelen in de keuze van mensen om al dan niet in de cluster te willen werken. In de EBB van 2000 zijn een groot aantal vragen hierover gesteld aan de ondervraagden. In tabel 4.2 wordt op basis hiervan een beeld gegeven van de reistijd, werktijden en de fysieke en psychische omstandigheden van het werk. Hierbij wordt binnen de lucht- en ruimtevaart een onderscheid gemaakt tussen de bouw en de luchtvaart en luchthavens. Als de situatie in één van beide deelsectoren significant afwijkt van het landelijk gemiddelde dan is dit cijfer vet gedrukt. De reistijd wordt aangegeven in minuten reistijd voor een enkele reis. Bij ploegendienst, en werken op zaterdag of zondag wordt het percentage werkenden waarvoor dit van toepassing is aangegeven. Voor de overige werkaspecten konden de respondenten kiezen uit drie antwoorden: 0 betekent niet van toepassing; 1 enigszins van toepassing; 2 betekent duidelijk van toepassing. In de tabel staat de gemiddelde score hiervan weergegeven. Deze varieert dus tussen de 0 en de 2.

Uit de tabel komt naar voren dat het werk bij de luchtvaart sterker afwijkt van het landelijk gemiddelde dan het werk in de vliegtuigbouw. Bovendien lijken bijna alle afwijkingen bij de luchtvaart minder gunstig te zijn. Bij de luchtvaart en luchthavens is de reistijd naar het werk aanzienlijk langer. Dit effect verandert niet als wordt gecorrigeerd voor het feit dat dit werk zich hoofdzakelijk in stedelijke gebieden afspeelt. Daarnaast komt werken in ploegendienst en werken op zaterdag en zondag veel vaker voor dan elders. Ten slotte geven werkenden bij de luchtvaart aan dat ze meer dan gemiddeld een hoog werktempo hebben, dit tempo niet in eigen hand hebben, niet zelf hun verlof kunnen bepalen, en opvallend vaak te maken hebben 
met conflicten met klanten. De verhouding tussen collega's en met leidinggevenden wijkt niet af van het landelijk gemiddelde.

\section{Tabel 4.2}

Reistijd, werktijden, fysieke en psychische omstandigheden van het werk in de vliegtuigbouw en de luchtvaart in vergelijking met de gehele Nederlandse arbeidsmarkt

\begin{tabular}{lrrr}
\hline & Nederland & Vliegtuigbouw & Luchtvaart \\
& & & \\
\hline & 27 & 31 & $\mathbf{4 8}$ \\
Reistijd (min) & 19 & 18 & $\mathbf{5 3}$ \\
Ploegendienst \% & 47 & 33 & $\mathbf{7 8}$ \\
Zaterdag \% & 27 & 17 & $\mathbf{7 7}$ \\
Zondag \% & 0,62 & $\mathbf{0 , 8 5}$ & 0,67 \\
Kracht & 0,31 & $\mathbf{0 , 9 2}$ & 0,68 \\
Lawaai & 0,24 & $\mathbf{0 , 6 9}$ & 0,12 \\
Trilling & 0,98 & $\mathbf{0 , 6 2}$ & 1,05 \\
Beeldscherm & 0,98 & $\mathbf{0 , 7 6}$ & $\mathbf{1 , 4 0}$ \\
Hoog werktempo & 0,65 & 0,74 & $\mathbf{0 , 9 8}$ \\
Tempo niet in eigen hand & 0,65 & $\mathbf{0 , 3 0}$ & $\mathbf{1 , 1 1}$ \\
Verlof niet zelf bepalen & 0,51 & $\mathbf{0 , 2 0}$ & $\mathbf{0 , 9 6}$ \\
Conflicten met klanten & 0,20 & 0,25 & 0,14 \\
Sfeer is slecht & 0,40 & 0,29 & 0,40 \\
Conflicten met collega's & 0.41 & 0.51 & 0.45 \\
Ontevreden over leiding & 0,53 & 0,48 & 0,63 \\
Conflicten met leiding & & & \\
& & & \\
\hline
\end{tabular}

Onderzocht is of deze verschillen verklaard kunnen worden door de specifieke samenstelling naar geslacht of opleiding binnen de luchtvaart, en of bepaalde beroepen een sterk afwijkend patroon laten zien. Samenstellingseffecten blijken niet te spelen. Daarnaast wijkt het werk van stewardessen en piloten op een aantal voorspelbare punten af van het grondpersoneel: er is nog meer sprake van onregelmatige werktijden en stewardessen werken veel minder met beeldschermen dan het grondpersoneel.

Het werk in de vliegtuigbouw wijkt veel minder af van het landelijk gemiddelde. Er is meer dan gemiddeld sprake van zwaar werk, lawaai en trilling, maar ook is de werkdruk lager en zijn er meer mogelijkheden om zelf verlofdagen te bepalen en zijn er minder conflicten met klanten. Dit patroon blijkt echter typisch te zijn voor heel veel technische bedrijven.

In tabel 4.3 wordt specifiek ingegaan op blootstelling aan gevaarlijke stoffen op het werk. Zoals verwacht kon worden heeft men met name in de vliegtuigbouw meer last van dampen van oplosmiddelen en in de luchtvaart van uitlaatgassen. Ook geven mensen bij de luchtvaart en luchthavens aan meer dan gemiddeld geconfronteerd te worden met huid-irriterende middelen en afval van groenten, fruit en planten. Omdat deze cijfers gezien moeten worden op de schaal van 0-2 zijn deze problemen echter 
niet erg dominant en lijken de werkomstandigheden die in tabel 4.2 aan de orde kwamen meer een algemeen probleem.

\section{Tabel 4.3}

Blootstelling aan gevaarlijke stoffen binnen de vliegtuigbouw en de luchtvaart in vergelijking met de gehele Nederlandse arbeidsmarkt

\begin{tabular}{lccc}
\hline & Nederland & Vliegtuigbouw & Luchtvaart \\
\hline Dampen van oplosmiddelen & & & \\
Uitlaatgassen & 0,03 & $\mathbf{0 , 1 9}$ & $\mathbf{0 , 0 8}$ \\
Huid irriterende middelen & 0,04 & $\mathbf{0 , 1 4}$ & $\mathbf{0 , 2 0}$ \\
Afval van groenten, fruit en planten & 0,06 & 0,08 & $\mathbf{0 , 1 0}$ \\
& 0,05 & $\mathbf{0 , 0 1}$ & $\mathbf{0 , 1 7}$ \\
\hline
\end{tabular}

Tot slot wordt in tabel 4.4 ingegaan op bedrijfsongevallen in de lucht- en ruimtevaart. Uit de cijfers blijkt dat in de vliegtuigbouw aanzienlijk meer bedrijfsongevallen plaatsvinden dan gemiddeld in Nederland. Dit verschil wordt echter in de meeste industriële sectoren aangetroffen en lijkt daarmee geen specifiek lucht- en ruimtevaartprobleem te zijn. Binnen de luchtvaart wijkt het percentage bedrijfsongevallen niet significant af van het landelijke gemiddelde.

Tabel 4.4

Bedrijfsongevallen binnen de vliegtuigbouw en de luchtvaart in vergelijking met de gehele Nederlandse arbeidsmarkt

\begin{tabular}{lccc} 
& Nederland & Vliegtuigbouw & Luchtvaart \\
\hline Ongeval & $1,3 \%$ & $\mathbf{4 , 0} \%$ & $1,0 \%$ \\
\hline
\end{tabular}





\section{De keuze voor de lucht- en ruimtevaart}

Gegevens uit de Enquête Beroepsbevolking geven alleen een beeld van de feitelijke verdeling van werkenden met een uiteenlopende opleidingsachtergrond over de beroepen en bedrijfssectoren. Naast de gegevens over werkomstandigheden die in de vorige paragraaf zijn gepresenteerd is er weinig bekend over beloning en arbeidsvoorwaarden en biedt deze enquête ook geen informatie over de motieven en overwegingen die bij de keuze een rol hebben gespeeld. Om echt goed zicht te krijgen op het keuzeproces van mensen zal een aanvullende enquête gehouden moeten worden. Uit de Schoolverlatersenquêtes (SIS) kan echter al, in aanvulling op de informatie uit de EBB, een preciezer beeld wordt gevormd over de keuze voor een viertal opleidingen die zich specifiek op de lucht- en ruimtevaart richten en de vervolgstappen van deze jongeren op de arbeidsmarkt.

Tabel 5.1 laat zien welk percentage van de schoolverlaters gaat werken in de luchten ruimtevaart. Het gaat hier om de opleidingen BOL/BBL luchtvaartdienstverlener, $\mathrm{BOL} / \mathrm{BBL}$ vliegtuigtechniek, HBO luchtvaarttechnologie en WO lucht- en ruimtevaarttechniek. Schoolverlaters zijn ongeveer anderhalf jaar na het behalen van het diploma geënquêteerd. Om over voldoende waarnemingen te beschikken zijn gegevens uit de jaren 1996-2000 samengenomen. De gepresenteerde gegevens blijken over de genoemde periode vrij constant te zijn. De opleiding BOL/BBL luchtvaartdienstverlener richt zich op het beroep steward(ess). Veel stewards en stewardessen volgen echter niet deze opleiding maar volgen na een andere vooropleiding een bedrijfsopleiding die meestal ongeveer een half jaar duurt. In de schoolverlatersenquête zijn een groot aantal afgestudeerden van andere opleidingen te vinden die via een dergelijke route steward(ess) zijn geworden. Hun opleidingsachtergrond loopt sterk uiteen. Een grote groep heeft alleen het VWO afgerond, maar er zijn ook veel schoolverlaters van $\mathrm{HBO}$ - en WO-opleidingen die deze richting zijn ingeslagen.

De tabel laat zien dat voor de twee MBO-opleidingen en HBO luchtvaarttechnologie, ongeveer anderhalf jaar na het behalen van het diploma, iets minder dan de helft van de schoolverlaters in de cluster werkzaam is. Een baan van een schoolverlater is toegerekend aan de lucht- en ruimtevaart als of het beroep een typische lucht- en ruimtevaartberoep is, of men werkzaam is in de sector. Schoolverlaters die werkzaam zijn in de lucht- en ruimtevaart hoeven dus niet per se ook in het beroep te werken waarvoor ze zijn opgeleid. Met name bij BOL/BBL luchtvaartdienstverlener blijkt ongeveer een op de vier schoolverlaters die werkt in de luchtvaart geen steward(ess) te zijn, maar een andere functie in de luchtvaart te hebben. Werkloosheid komt vrijwel niet voor. Echter met name bij de twee technische richtingen op MBO- en $\mathrm{HBO}-$ niveau heeft een aanzienlijk deel van de schoolverlaters geen werk. De reden hiervoor is vrijwel altijd dat men doorgestroomd is naar een andere opleiding. In een groot aantal gevallen is dat een vergelijkbare technische opleiding op een hoger niveau. Bij BOL/BBL luchtvaartdienstverlener en WO luchten ruimtevaarttechniek is het percentage afgestudeerden dat niet werkt vrij laag. 
Met name bij WO lucht- en ruimtevaarttechniek is het percentage afgestudeerden dat niet bij bedrijven binnen de cluster werkt erg hoog. Maar liefst $69 \%$ van de afgestudeerden van deze opleiding werken buiten de lucht- en ruimtevaart. Zowel uit gesprekken met betrokkenen als uit de cijfers komt naar voren dat deze afgestudeerden makkelijk werk kunnen vinden in andere technische sectoren. De competenties die men tijdens de opleiding heeft verworven blijken ook in andere technische bedrijven zeer gewaardeerd te worden.

Ook schoolverlaters van de andere technische opleidingen die niet in de lucht- en ruimtevaart terecht zijn gekomen werken meestal in een technische functie in een andere sector. Bij BOL/BBL luchtvaartdienstverlener hebben de meeste gediplomeerden die niet in de lucht- en ruimtevaart werken, werk gevonden in de horeca of in een winkel. Met name bij deze groep blijkt men veel minder aan de opleiding te hebben gehad als men niet daadwerkelijk als steward(ess) gaat werken. In hun geval lijkt er dan ook duidelijk sprake te zijn van onbenutte competenties als men elders gaat werken.

Tabel 5.1

Verdeling van schoolverlaters over werk in de lucht- en ruimtevaart, ander werk en geen werk (opleiding, werkloos of non-participatie)

\begin{tabular}{lrrrr}
\hline Opleiding & $\begin{array}{r}\text { Lucht- en } \\
\text { ruimtevaart } \\
\%\end{array}$ & $\begin{array}{r}\text { Ander } \\
\text { werk } \\
\%\end{array}$ & $\begin{array}{r}\text { Geen } \\
\text { werk } \\
\%\end{array}$ & $\begin{array}{r}\text { Totaal } \\
\%\end{array}$ \\
\hline BOL/BBL luchtvaartdienstverlener & 44 & 47 & 10 & 100 \\
BOL/BBL vliegtuigtechniek & 41 & 29 & 31 & 100 \\
HBO luchtvaarttechnologie & 47 & 31 & 23 & 100 \\
WO lucht- en ruimtevaarttechniek & 25 & 69 & 7 & 100 \\
\hline
\end{tabular}

Tabel 5.2

Het gemiddeld uurloon van schoolverlaters binnen en buiten de lucht- en ruimtevaart

\begin{tabular}{lcc}
\hline & $\begin{array}{r}\text { Lucht- en ruimtevaart } \\
\text { fl/uur }\end{array}$ & $\begin{array}{c}\text { Ander werk } \\
\text { fl/uur }\end{array}$ \\
\hline BOL/BBL luchtvaartdienstverlener & 17,45 & 16,97 \\
BOL/BBL vliegtuigtechniek & 19,96 & 15,50 \\
HBO luchtvaarttechnologie & 23,58 & 22,72 \\
WO lucht- en ruimtevaarttechniek & 27,88 & 28,18 \\
\hline
\end{tabular}

Tabel 5.2 geeft een overzicht van de salariëring van de schoolverlaters. Over het algemeen blijken er weinig verschillen te zijn in de beloning die men krijgt als men gaat werken in de lucht- en ruimtevaart in vergelijking met andere functies. Alleen schoolverlaters van BOL/BBL vliegtuigtechniek verdienen aanmerkelijk minder als ze 
niet in de lucht- en ruimtevaart gaan werken. Het ontbreken van een beloningsverschil bij BOL/BBL luchtvaartdienstverlener is opmerkelijk, omdat ook geconstateerd is dat men buiten de lucht- en ruimtevaart de ontwikkelde competenties veel minder goed benut. Uit gesprekken kwam naar voren dat juist de betere studenten van WO lucht- en ruimtevaarttechniek doorstromen naar de eigen sector. Als dat inderdaad het geval is is ook hier het ontbreken van een duidelijk beloningsverschil opmerkelijk.

In tegenstelling tot de beloning, blijkt er wel een systematisch verschil te zijn tussen werk binnen en buiten de lucht- en ruimtevaart voor wat betreft het krijgen van een vaste aanstelling. Uit tabel 5.3 komt naar voren dat met uitzondering van HBO luchtvaarttechnologie schoolverlaters steeds buiten de cluster meer kans blijken te hebben op een vaste aanstelling.

Tabel 5.3

Percentage schoolverlaters met een vaste aanstelling binnen en buiten de lucht- en ruimtevaart

\begin{tabular}{lrr}
\hline & $\begin{array}{r}\text { Lucht- en } \\
\text { ruimtevaart } \\
\%\end{array}$ & $\begin{array}{r}\text { Ander werk } \\
\%\end{array}$ \\
\hline BOL/BBL luchtvaartdienstverlener & 57 & 68 \\
BOL/BBL vliegtuigtechniek & 50 & 65 \\
HBO luchtvaarttechnologie & 52 & 50 \\
WO lucht- en ruimtevaarttechniek & 46 & 57 \\
\hline
\end{tabular}

Hoewel het interessant is om verschillen in beloning en arbeidsvoorwaarden binnen en buiten de cluster te vergelijken, kan men uit deze cijfers geen harde conclusies trekken over de concurrentiepositie van de lucht- en ruimtevaart. Uit het theoretisch kader in hoofdstuk 2 kwam immers naar voren dat er grote verschillen zullen zijn in de voorkeuren van mensen voor bepaalde beroepen. Als veel mensen werk in een bepaald lucht- en ruimtevaartberoep aantrekkelijk vinden, kan dat een relatief laag beloningsniveau verklaren. Verder zullen mensen bij hun beroepskeuze niet alleen het salaris, maar ook de werkomstandigheden, zoals beschreven in hoofdstuk 4 in overweging nemen. Ook hierbij kan het salaris verschillen in omstandigheden compenseren. Men spreekt dan van compenserende loonsverschillen.

Om duidelijk te krijgen in hoeverre de inhoud van de baan, de beloning en de secundaire arbeidsomstandigheden en de werkomstandigheden als geheel pakket overeenkomen met de (vage) verwachtingen die men hierover had toen de studiekeuze werd gemaakt, is aan schoolverlaters gevraagd of ze achteraf gezien, als ze de studiekeuze opnieuw zouden kunnen maken, opnieuw dezelfde opleiding zouden hebben gekozen. Als men aanneemt dat schoolverlaters die de gehele opleiding hebben doorlopen, in een groot aantal gevallen zelf ervaring in het betreffende beroep hebben opgedaan en in ieder geval jaargenoten zullen kennen die in de cluster werkzaam zijn, een beter beeld hebben van de voor- en nadelen van 
werken in de lucht- en ruimtevaart dan toen men nog voor de studiekeuze stond, dan is deze spijtvraag een goede indicator voor de mate waarin een verkeerd beeld van het beroep de studiekeuze heeft beïnvloed.

Gemiddeld over alle opleidingen in Nederland ligt het percentage schoolverlaters dat spijt zegt te hebben van de opleidingskeuze rond de $20 \%$. Uit tabel 5.4 komt naar voren dat met name bij BOL/BBL luchtvaartdienstverlening dit spijtpercentage erg hoog ligt. Maar liefst $58 \%$ van de schoolverlaters geeft aan dat men achteraf gezien liever een andere opleiding had willen kiezen. Er blijkt geen duidelijk patroon te zitten in de alternatieven die achteraf gezien de voorkeur zouden hebben gehad. Omdat het hier voor een groot deel om vrouwen gaat worden met name typische vrouwenopleidingen genoemd. In tabel 5.5 wordt het percentage schoolverlaters dat spijt heeft van de opleiding uitgesplitst naar degenen die werkzaam zijn in de lucht- en ruimtevaart, degenen met ander werk en degenen die niet werken. Hoewel degenen die niet in de lucht- en ruimtevaart werken vaker spijt zeggen te hebben dan degenen die wel in de cluster werken is ook bij deze groep het percentage met spijt hoog. Nadere analyse wijst uit dat er geen verband bestaat met de aard van het contact (vast of niet) of de hoogte van het salaris. Kennelijk heeft een zeer groot deel van de leerlingen die gekozen hebben voor BOL/BBL luchtvaartdienstverlener een verkeerd beeld gehad van het beroep steward(ess) of heeft men niet in kunnen schatten of dit beroep bij hen past.

Tabel 5.4

Percentage schoolverlaters met spijt van de opleidingskeuze

\begin{tabular}{lc}
\hline & $\begin{array}{c}\text { Spijt van de opleiding } \\
\%\end{array}$ \\
\hline BOL/BBL luchtvaartdienstverlener & 58 \\
BOL/BBL vliegtuigtechniek & 25 \\
HBO luchtvaarttechnologie & 25 \\
WO lucht- en ruimtevaarttechniek & 17 \\
\hline
\end{tabular}

Ook bij de technische opleidingen op MBO- en HBO-niveau ligt de spijt iets boven het gemiddelde van $20 \%$. Hier blijken echter met name degenen die niet in de luchten ruimtevaart zijn gaan werken spijt te hebben. Bij de WO-opleiding ligt het spijtniveau lager, en bestaat er zeker binnen de groep die binnen de cluster werkt weinig ontevredenheid over de gemaakte opleidingskeuze. Opvallend is dat ook voor de grote groep afgestudeerden die niet in de lucht- en ruimtevaart is gaan werken het spijtpercentage relatief laag is. Dit lijkt te bevestigen dat deze groep de cluster niet heeft verlaten omdat ze tijdens de opleiding tot het inzicht zijn gekomen dat werken in de lucht- en ruimtevaart hen niet bevalt, maar dat het hen niet zo veel uitmaakt of ze al dan niet in de lucht- en ruimtevaart werken, en ze wellicht zelfs een weloverwogen keuze hebben gemaakt om via de WO-opleiding lucht- en ruimtevaarttechniek een loopbaan in de techniek te beginnen, zonder een uitgesproken voorkeur om ook daadwerkelijk in deze sector te gaan werken. 
Tabel 5.5

Percentage schoolverlaters met spijt van de opleidingskeuze uitgesplitst naar degenen die werkzaam zijn in de lucht- en ruimtevaart, degenen met ander werk en degenen die niet werken

\begin{tabular}{lrrr}
\hline & $\begin{array}{r}\text { L\&R } \\
\text { Spijt } \\
\%\end{array}$ & $\begin{array}{r}\text { Ander werk } \\
\text { Spijt } \\
\%\end{array}$ & $\begin{array}{r}\text { geen werk } \\
\text { Spijt } \\
\%\end{array}$ \\
\hline BOL/BBL luchtvaartdienstverlener & 51 & 65 & 47 \\
BOL/BBL vliegtuigtechniek & 19 & 41 & 17 \\
HBO luchtvaarttechnologie & 23 & 32 & 20 \\
WO lucht- en ruimtevaarttechniek & 8 & 20 & 23 \\
\hline
\end{tabular}

\section{Tabel 5.6}

De balans tussen de aantallen leerlingen die een lucht- en ruimtevaartopleiding hebben gedaan en er spijt van hebben en degenen die een andere opleiding hebben gedaan en achteraf gezien juist wel een opleiding in de lucht- en ruimtevaart hadden willen doen (als percentage van het aantal schoolverlaters met een lucht- en ruimtevaartopleiding)

\begin{tabular}{|c|c|c|c|c|c|c|}
\hline & \multicolumn{3}{|c|}{ Alle beroepen } & \multicolumn{3}{|c|}{ Alleen de lucht- en ruimtevaart } \\
\hline & $\begin{array}{r}\text { Verlies } \\
\%\end{array}$ & $\begin{array}{r}\text { Winst } \\
\%\end{array}$ & $\begin{array}{r}\text { Balans } \\
\%\end{array}$ & $\begin{array}{r}\text { Verlies } \\
\%\end{array}$ & $\begin{array}{r}\text { Winst } \\
\%\end{array}$ & $\begin{array}{r}\text { Balans } \\
\%\end{array}$ \\
\hline $\begin{array}{l}\text { BOL/BBL } \\
\text { luchtvaartdienstverlener }\end{array}$ & 58 & 24 & -34 & 52 & 72 & +20 \\
\hline $\begin{array}{l}\text { BOL/BBL } \\
\text { vliegtuigtechniek }\end{array}$ & 25 & 11 & -14 & 19 & 27 & +8 \\
\hline $\begin{array}{l}\text { HBO } \\
\text { luchtvaarttechnologie }\end{array}$ & 25 & 19 & -6 & 23 & 40 & +17 \\
\hline $\begin{array}{l}\text { WO lucht- en ruimtevaart- } \\
\text { techniek }\end{array}$ & 17 & 4 & -13 & 8 & 16 & +8 \\
\hline
\end{tabular}

Net zoals er leerlingen met een luchtvaartgerelateerde opleiding zijn die achteraf constateren dat ze liever een andere opleiding hadden willen kiezen, zo zijn er ook schoolverlaters met een andere opleidingsachtergrond die achteraf constateren dat zij juist liever wel een opleiding voor de lucht- en ruimtevaart hadden willen volgen. In theorie zou men kunnen zeggen dat bij een perfecte voorlichting over de aard van het beroep degenen die nu spijt hebben van een opleiding in de lucht- en ruimtevaart niet in deze richting zouden zijn gaan studeren, terwijl mensen die een andere opleiding hebben gedaan, maar achteraf aangeven dat ze juist liever wel een luchten ruimtevaartopleiding hadden gedaan wel in deze opleidingen zouden zijn ingestroomd. In tabel 5.6 wordt de balans van beide grootheden opgemaakt. Hierbij kan men verschillende veronderstellingen hanteren. In de eerste drie kolommen wordt tegenover het totale percentage schoolverlaters dat spijt heeft van een van de vier genoemde opleidingen aangegeven hoeveel schoolverlaters van andere studierichtingen achteraf gezien liever juist wel een van deze vier richtingen hadden willen doen. Dit aantal is als percentage van het aantal schoolverlaters uit de luchtvaartgerelateerde opleidingen genomen. Bij alle vier de studierichtingen zou er 
als iedereen een keuze zou maken die achteraf als wenselijk wordt gezien een verlies optreden. Tegenover de 58\% schoolverlaters BOL/BBL luchtvaartdienstverlener die verloren zouden gaan staat bijvoorbeeld een toename van $24 \%$ door de toestroom uit andere opleidingen. Vanuit dit perspectief is het imago van de opleiding gemiddeld genomen te goed. Er zijn meer leerlingen die ten onrechte voor een van de vier luchtvaartopleidingen keizen dan dat er leerlingen zijn die dit ten onrechte niet doen.

Deze rechtstreekse vergelijking houdt echter geen rekening met het feit dat mogelijk mede door deze onjuiste studiekeuzes - een deel van de afgestudeerden toch al niet in de sector gaat werken. Als de balans alleen wordt opgemaakt voor alleen de schoolverlaters die gaan werken in de lucht- en ruimtevaart en de (wellicht extreme) veronderstelling wordt gemaakt dat iedereen die ten onrechte niet voor een van deze vier opleidingen heeft gekozen een baan in de cluster zou krijgen, dan zou tegenover een kleiner verlies een grotere toestroom van nieuw aanbod staan. Bij alle vier de genoemde opleidingsrichtingen zou er in dit extreem scenario meer winst dan verlies zijn als leerlingen zich gebaseerd zouden hebben op perfecte informatie. In de praktijk zal echter ook een deel van deze "nieuwe toestroom" buiten de lucht- en ruimtevaart gaan werken en zal de werkelijke balans tussen de twee genoemde extremen uitvallen. 


\section{De ontwikkelingen bij Fokker ${ }^{10}$}

Omdat het faillissement van Fokker een zeer belangrijke recente gebeurtenis is geweest in de ontwikkeling van de arbeidsmarkt voor de lucht- en ruimtevaart in Nederland, gaan we in dit hoofdstuk specifiek in op de gevolgen die deze gebeurtenis heeft gehad. Het belang hiervan is dat uit de manier waarop de veelal goed opgeleide werknemers van dit high-tech bedrijf op zoek zijn gegaan naar andere werk, veel informatie kan worden gehaald over de mogelijkheden die deze werknemers hebben om ook elders aan de slag te gaan en over de arbeidsmarktpositie van de Nederlandse lucht- en ruimtevaart in vergelijking met andere sectoren.

Op 15 maart 1996 werd voor N.V. Koninklijke Nederlandse Vliegtuigfabriek Fokker, Fokker Aircarft B.V. en Fokker Administration B.V. faillissement aangevraagd. Door het faillissement van Fokker heeft het cluster lucht- en ruimtevaart een boegbeeld binnen hun groep verloren, een bedrijf dat ook nog eens een tastbaar en "trots" product afleverde. De Fokker 50, 70 en 100 waren vliegtuigen die binnen hun productgroep tot de besten behoorden. Het faillissement ging gepaard met een groot aantal gedwongen ontslagen. 5.644 medewerkers waren in loondienst bij onderdelen van Fokker die onder het faillissement vielen. Voor het merendeel van deze werknemers was de dag van het faillissement het einde van hun baan bij Fokker. Het Business Investment Research Center aan de Universiteit Maastricht heeft na het faillissement een enquête ontwikkeld, die de situatie van voormalige Fokker medewerkers in kaart moest brengen. Deze zogenaamde "Fokker-Enquête" werd gestuurd naar alle mensen die op de dag van het faillissement nog in dienst waren van Fokker. ${ }^{11}$

In dit hoofdstuk wordt ingegaan op een drietal vragen. Ten eerste wordt bekeken naar welke werkgevers de ontslagen Fokker medewerkers zijn gegaan. Hier is natuurlijk vooral van belang of de werknemers naar bedrijven gaan die binnen of buiten de cluster lucht- en ruimtevaart valt. Ten tweede wordt ingegaan op het verschil in salaris, opleiding, en functieniveau tussen de werknemers die binnen de cluster blijven en diegene die buiten de cluster emplooi. De derde vraag is in hoeverre werknemers hun carrière in de lucht- en ruimtevaart voort willen en kunnen zetten.

\section{Nieuwe werkgevers}

Tabel 6.1 geeft een overzicht van sectoren waar voormalige Fokkerwerknemers hun eerste en de huidige banen gevonden hebben. Opvallend is dat voor $35,2 \%$ de eerste baan tevens de huidige baan is. De overige $64,8 \%$ van de respondenten wisselde tenminste één maal van werkgever gedurende de periode van drie jaar na het faillissement. Een voorbeeld van een sector waarin in eerste instantie relatief veel (6,7 procent) mensen werk vonden, zijn de uitzendbureaus. Andere bedrijven die vrij

10. Aan dit hoofdstuk is meegewerkt door Ben Kriechel, BIRC, Universiteit Maastricht.

11. Zie Pfann et al. (2001) voor meer informatie over de Fokker-enquête. 
snel veel mensen in dienst hebben genomen, behoren tot de sectoren "Metaalindustrie" (8,2 procent), "Transportmiddelen" (3 procent), "Vliegtuigbouw en onderhoud" (6,0 procent). Verder boden de "IT-Industrie" (5 procent) en de "Luchtvaart" (3,2 procent) aan de ontslagen medewerkers een nieuw onderkomen.

Tabel 6.1

Sectoren waarin ex-Fokkerwerknemers werk vonden (bron Fokker Enquête, BIRC)

\begin{tabular}{|c|c|c|}
\hline & $\begin{array}{r}\text { Eerste baan } \\
\%\end{array}$ & $\begin{array}{r}\text { Huidige baan } \\
(1999) \\
\%\end{array}$ \\
\hline Geselecteerd & 38,5 & 19,6 \\
\hline Curator & 25,9 & 0,9 \\
\hline Fokker Aviation/STORK & 12,6 & 18,7 \\
\hline Industrie & 27,9 & 36,3 \\
\hline Voeding & 0,8 & 1,1 \\
\hline Chemisch en Farmaceutisch & 0,9 & 1,6 \\
\hline Papier & 0,5 & 0,2 \\
\hline Metaal & 8,2 & 9,6 \\
\hline Machines & 0,6 & 1,0 \\
\hline Electronica en Optisch & 2,6 & 2,4 \\
\hline Transport & 3,0 & 3,7 \\
\hline Vliegtuig (incl. onderhoud) & 6,0 & 9,8 \\
\hline Anders & 5,5 & 6,7 \\
\hline Commercial Services & 14,8 & 16,0 \\
\hline IT & 5,1 & 8,9 \\
\hline Engeneering & 0,6 & 1,4 \\
\hline Uitzendkrachten & 6,7 & 2,0 \\
\hline Anders & 2,8 & 3,7 \\
\hline Transport, Opslag en Telecommunicatie & 6,1 & 10,1 \\
\hline Luchtvaartmaatschappijen & 3,2 & 6,6 \\
\hline Telecommunicatiebedrijven & 1,9 & 2,6 \\
\hline Anders & 1,0 & 1,0 \\
\hline Andere Sectoren & 10,0 & 16,3 \\
\hline Utiliteiten & 0,5 & 0,2 \\
\hline Bouw & 2,2 & 2,4 \\
\hline Handel en commercie & 1,6 & 2,5 \\
\hline Horeca & 0,3 & 0,6 \\
\hline Financiële instellingen & 1,7 & 2,4 \\
\hline Gezondheidszorg & 0,7 & 1,5 \\
\hline Overheidsinstellingen & 1,9 & 4,5 \\
\hline Sociale Instellingen & 0,2 & 0,3 \\
\hline Onderwijs & 0,6 & 1,4 \\
\hline Landbouw en Visserij & 0,3 & 0,7 \\
\hline Anders & 2,8 & 1,7 \\
\hline Totaal & 100 & 100 \\
\hline
\end{tabular}

Wanneer de gegevens van de eerste baan worden vergeleken met die van de huidige baan, blijkt een omvangrijke mobiliteit van de werknemers tussen de verschillende sectoren te hebben bestaan. Hierdoor kwam de uiteindelijke herverdeling van arbeid over de verschillende sectoren tot stand. Van alle respon36 
denten die in de periode van drie jaar meer dan één werkgever hebben gehad, is $12,6 \%$ gestart bij Fokker Aviation. Van alle respondenten met slechts één werkgever in die periode is $18,7 \%$ in dienst van Stork/Aviation.

Drie jaar na het faillissement blijkt de sector voor tijdelijk uitzendwerk niet meer zo belangrijk te zijn en geeft nog slecht $2 \%$ van de respondenten aan dat hun huidige werk via een uitzendbaan wordt verricht. Voorbeelden van sectoren waar het aantal voormalige werknemers van Fokker toeneemt, zijn de metaalindustrie (van 8,2 naar $9,6 \%$ ), de vliegtuigindustrie (van 6 naar 9,8\%), luchtvaartmaatschappijen (van 3,2 naar $6,6 \%$ ) en in de sectoren van de snel groeiende informatietechnologie (van 5,1 naar $8,9 \%)$.

Het ligt voor de hand dat de meeste Fokkerwerknemers hun weg wisten te vinden naar bedrijven met vergelijkbaar werk als dat bij Fokker. Een andere mogelijkheid is dat door het faillissement van Fokker een aantal bedrijven langzaam maar zeker een deel van de activiteiten van Fokker overneemt. Dit is goed voor te stellen voor ondernemingen in de metaal- en de transportindustrie.

Tabel 6.2 geeft een overzicht van de lengte van contracten voor de eerste baan en de huidige baan. Opvallend is dat in eerste instantie betrekkelijk veel mensen $(43,1 \%)$ werk vonden met een tijdelijk contract zonder een garantie of zicht op een vaste aanstelling. In de huidige werksituaties is dit heel anders. Echter na drie jaar heeft meer $76,3 \%$ van alle respondenten een vast contract en heeft $13,4 \%$ een tijdelijk contract met uitzicht op een vast dienstverband.

Tabel 6.2

Aanstellingscontracten van ex-Fokkerwerknemers (bron Fokker Enquête, BIRC)

\begin{tabular}{lrr}
\hline & Eerste baan & $\begin{array}{r}\text { Huidige baan } \\
(1999) \\
\%\end{array}$ \\
& $\%$ & 1,1 \\
& & 7,1 \\
Oproepkracht & 5,4 & 13,4 \\
Tijdelijk zonder lange-termijn perspectieven & 37,7 & 2,0 \\
Tijdelijk met lange-termijn perspectieven & 29,6 & 76,3 \\
Proefperiode & 7,0 & 100 \\
Vast contract & 20,5 & 100 \\
Totaal & & \\
\end{tabular}

Een belangrijke vraag die zich voordoet bij de grote uitstroom van veelal ervaren werknemers die zich voordeed bij het faillissement van Fokker is of deze werknemers in hun nieuwe baan de kennis die ze bij Fokker op hebben gedaan opnieuw konden gebruiken. Tabel 6.3 laat zien dat in een groot aantal gevallen de algemene werkervaring of zowel de algemene als de technische werkervaring van belang waren. $40 \%$ van de ex-Fokkerwerknemers geeft aan dat de technische werkervaring van belang was voor het krijgen van nieuw werk. 
Tabel 6.3

Het belang van werkervaring voor het krijgen van een nieuwe baan (bron Fokker Enquête, $\mathrm{BIRC)}$

\begin{tabular}{lrr}
\hline & eerste baan & $\begin{array}{r}\text { huidige baan } \\
(1999)\end{array}$ \\
\hline Ja, met name algemene ervaring & 18,5 & 21,6 \\
Ja, met name technische ervaring & 5,0 & 3,9 \\
Ja, zowel algemene als technische ervaring & 13,1 & 37,5 \\
Nee, maar het helpt & 21,5 & 21,6 \\
Nee, niet nodig & 21,9 & 15,4 \\
Totaal & 100 & 100 \\
\hline
\end{tabular}

Werknemers die aansluitend aan het faillissement nieuw werk moeten zoeken staan voor moeilijke keuzes: Moeten zij proberen hun vakkennis te gebruiken om een vergelijkbare baan zowel qua niveau als qua inhoud zoeken of is het verstandiger om zich breder te oriënteren en een eventueel verlies van kennis en ervaring op de koop toe te nemen? Het resultaat van het faillissement van Fokker was dat een aantal werknemers zo snel mogelijk probeerde werk te vinden, ook al was het onder hun voormalig werkniveau, of buiten hun specialisme. Anderen hebben langer gezocht en gepoogd een baan te vinden die aansloot op hun vakkennis, sommigen waarschijnlijk ook tevergeefs. Weinig werknemers waren bereid om voor hun carrière binnen de vliegtuigbouw ook naar het buitenland te verhuizen, maar enkelen maakten de tocht naar Seattle, München, of Toulouse, waar zij hun vakkennis direct konden gebruiken. Binnen Nederland waren ook mogelijkheden om hun vakkennis te benutten, soms binnen het luchtvaartcluster (luchtvaartindustrie plus luchtvaart), soms ook in sectoren die technisch weliswaar vergelijkbare kennis vereisten, maar niet tot het luchtvaartcluster behoorden. Voorbeelden zijn de scheepsbouw, het bouwen en ontwikkelen van pijpleidingen, ingenieursbureaus. Ook academisch instituten wilden graag gebruik maken van de kennis uit de jaren van Fokker.

In de enquête is indien dit van toepassing was gevraagd wat de overwegingen waren om een baan te weigeren. Redenen die vaak genoemd waren zijn een te laag salaris $(20 \%)$, een te lage functie $(8 \%)$, een tijdelijke dienstverband $(8 \%)$ en een te grote reisafstand $(11 \%)$. De resterende $53 \%$ zijn verschillende, individuele redenen. Meestal werd een beter aanbod geaccepteerd of men wilde niet verhuizen. Maar ook de onzekerheid over de toekomstperspectieven van een baan of bedrijf speelden een rol om een aanbod niet aan te nemen. Ook de werkomstandigheden, dus werktijden en de werksfeer spelen hierbij mee. Uit eerder onderzoek blijkt dat werknemers terughoudend zijn om voor een nieuwe baan te verhuizen. Vooral wanneer de nieuwe baan niet precies aansluit op hun wensen of onvoldoende zekerheid biedt. Dit heeft met de hoogte van de aanpassingskosten te maken, die iemand moet opbrengen om te verhuizen. Deze kosten zijn hoger indien een familie mee moet verhuizen. Hoger opgeleide werkzoekenden zijn eerder geneigd om te verhuizen. De verschillen in salaris zijn voor hen groter zodat verhuiskosten relatief minder zwaar wegen. 
Salarissen die in de verschillende sectoren betaald worden, kunnen nogal verschillen. Tabel 6.4 geeft de loonverschillen weer voor de groep van werknemers die binnen de cluster lucht- en ruimtevaart blijft (hier gedefinieerd als de sector "Vliegtuigbouw", "Fokker Aviation / Stork", en "Luchtvaart"). Ter vergelijking kijken wij naar loonverschillen van alle overige werknemers die een baan elders gevonden hebben. Het loonverschil is gedefinieerd als het maandsalaris in de laatste baan minus het maandsalaris bij Fokker ten tijde van het faillissement. De loonverschillen voor werknemers die geselecteerd werden voor Fokker Aviation zijn gemiddeld het grootst. Deze groep werknemers blijkt de minste last van het faillissement te hebben. Zij kunnen hoogstwaarschijnlijk hun kennis direct toepassen en worden er ook naar betaald. Ook speelt een selectie-effect mee, omdat deze groep van werknemers uit een grotere groep werknemers van het failliete Fokker gekozen werden. Opvallend is wel dat de twee andere sectoren binnen de cluster "Lucht- en Ruimtevaart" juist minder goed betalen: zowel in de luchtvaartindustrie als in de luchtvaart liep het loon van ex-Fokkerwerknemers met gemiddeld respectievelijk 29 gulden en 228 gulden terug. Werknemers die in de industrie terechtkwamen gingen er gemiddeld 38 gulden op hun maandsalaris in vooruit. Het zou normaalgesproken verwacht mogen worden, dat werknemers die binnen de cluster blijven ook meer verdienen omdat het aannemelijk is dat zij hun vak- ofwel clusterspecifieke kennis en ervaring in het nieuwe bedrijf gebruiken.

\section{Tabel 6.4}

Gemiddeld Loonverschil in guldens per maand t.o.v. het laatste Fokker-salaris (bron Fokker Enquête, BIRC)

toename salaris in guldens per maand

\section{Cluster L\&R}

Fokker Aviation

Vliegtuigbouw (andere bedrijven)

Luchtvaart

Andere sectoren

Industrie

In de Fokker Enquête werden de respondenten ook gevraagd om een inschatting te geven of hun huidige functie vergelijkbaar is met de functie die zij bij Fokker hadden. Tabel 6.5 geeft hiervan een overzicht. Opvallend is dat een groter aantal medewerkers buiten de cluster lucht- en ruimtevaart aangeeft "veel meer" verantwoording te dragen. Indien wij slechts bekijken of meer verantwoording in de nieuwe baan gegeven wordt, zo blijkt het cluster vergelijkbaar te zijn met alle andere werkgevers. Slechts de luchtvaart scoort hier beduidend lager. Meer respondenten geven bij de luchtvaart aan in functies te werken op of onder het verantwoordingsniveau van Fokker. 
Tabel 6.5

Verantwoordelijkheid huidige baan ten opzichte van werk bij Fokker (bron Fokker Enquête, $\mathrm{BIRC})$

\begin{tabular}{|c|c|c|c|c|c|c|}
\hline & $\begin{array}{r}\text { veel } \\
\text { meer } \\
\%\end{array}$ & $\begin{array}{r}\text { meer } \\
\%\end{array}$ & $\begin{array}{r}\text { zelfde } \\
\%\end{array}$ & $\begin{array}{r}\text { minder } \\
\%\end{array}$ & $\begin{array}{r}\text { veel } \\
\text { minder } \\
\%\end{array}$ & $\begin{array}{r}\text { Totaal } \\
\%\end{array}$ \\
\hline \multicolumn{7}{|l|}{ L\&R } \\
\hline Fokker Aviation & 15 & 37 & 38 & 9 & 2 & 100 \\
\hline Vliegtuigbouw & 17 & 29 & 30 & 20 & 4 & 100 \\
\hline Luchtvaart & 9 & 24 & 34 & 24 & 8 & 100 \\
\hline \multicolumn{7}{|l|}{ Andere sectoren } \\
\hline Industrie & 22 & 31 & 29 & 14 & 4 & 100 \\
\hline Commercial Services & 17 & 32 & 31 & 13 & 7 & 100 \\
\hline $\begin{array}{l}\text { Transport, opslag en } \\
\text { communicatie }\end{array}$ & 18 & 31 & 28 & 17 & 6 & 100 \\
\hline Overige & 19 & 33 & 31 & 12 & 5 & 100 \\
\hline Gemiddeld & 18 & 32 & 32 & 14 & 5 & 100 \\
\hline
\end{tabular}

Tabel 6.6

Belang van beroepservaring en technische kennis in huidige functie (bron Fokker Enquête, $\mathrm{BIRC})$

\begin{tabular}{|c|c|c|}
\hline $\begin{array}{l}\text { alleen algemene } \\
\text { beroepservaring }\end{array}$ & technische kennis & $\begin{array}{c}\text { technische kennis en } \\
\text { algemene } \\
\text { beroepservaring }\end{array}$ \\
\hline
\end{tabular}

\section{L\&R}

Fokker Aviation

Vliegtuigbouw

Luchtvaart

23
16
8

66

71

69

\section{Andere sectoren}

Industrie

Commercial Services

Transport, opslag en

communicatie

Overige

$\begin{array}{lll}22 & 4 & 32 \\ 34 & 3 & 29 \\ 30 & 3 & 21 \\ 27 & 5 & 21 \\ 24 & 4 & 42\end{array}$

Gemiddeld

24

42

Als gekeken wordt naar de relevantie van de ervaring, dan scoort het cluster Luchten Ruimtevaart wel hoog. Uit tabel 6.6. blijkt dat vooral binnen de cluster beroep- en technische kennis van Fokkerianen gewaardeerd worden. Opvallend is dat in de luchtvaart vooral ook de technische kennis gevraagd wordt. Daar tegenover staan de sectoren buiten de cluster, die vooral werknemers een baan hebben aangeboden op basis van hun beroepservaring. 


\section{Wat gebeurt er als de lucht- en ruimtevaart groter wordt? Een vergelijking met de VS}

Omdat de belangstelling van mensen voor werk in de lucht- en ruimtevaart deels gebaseerd is op persoonlijke voorkeur en deels gebaseerd is op arbeidsmarktfactoren zal het bij het groter worden van de vraag naar personeel steeds moeilijker worden om te profiteren van de inhoudelijke belangstelling voor het vak. Er zal immers steeds meer een beroep gedaan moeten worden op mensen die geen uitgesproken interesse voor een loopbaan in de lucht- en ruimtevaart zullen hebben en dus zullen arbeidsvoorwaarden steeds meer de doorslag moeten geven.

Om inzicht te krijgen in welke mate een toename van de vraag zal leiden tot duurder worden van het personeel, moet een vergelijking gemaakt worden tussen situaties waarin de omvang van de lucht- en ruimtevaart varieert. Omdat in Nederland dergelijk vergelijkingsmateriaal niet te vinden is, wordt in dit hoofdstuk ingegaan op de arbeidsmarkt voor de lucht- en ruimtevaart in de VS. Doordat in de verschillende staten van de VS het belang van de lucht- en ruimtevaart sterk uiteenloopt kan onderzocht worden hoe de beloning van diverse groepen in de cluster afhangt van de omvang van de vraag. Door Nederland te plaatsen in deze range van staten kan daarmee ook bekeken worden welke gevolgen een uitbreiding van de vraag in de lucht- en ruimtevaart in Nederland zou hebben.

Tabel 7.1

De omvang van de luchtvaart en luchthavens in Nederland in vergelijking met de staten van de VS

$\%$ van totale beroepsbevolking

\begin{tabular}{llr}
\hline & Alaska & 3,04 \\
2 & Hawaii & 1,97 \\
3 & Georgia & 1,52 \\
4 & Minnesota & 1,47 \\
5 & Oklahoma & 1,38 \\
& Virginia & \\
23 & New Jersey & 0,54 \\
24 & Nederland & 0,52 \\
& Montana & 0,50 \\
25 & Michigan & 0,49 \\
26 & North Dakota & 0,48 \\
& South Dakota & \\
49 & Rhode Island & 0,22 \\
50 & & 0,21 \\
51 & & 0,17 \\
& &
\end{tabular}


Tabel 7.2

De omvang van de vliegtuigbouwsector in Nederland in vergelijking met de staten van de VS

\begin{tabular}{llr}
\hline & & \\
& $\begin{array}{r}\text { \% van totale } \\
\text { beroepsbevolking }\end{array}$ \\
\hline & Kansas & 3,56 \\
2 & Washington & 3,19 \\
3 & Connecticut & 2,62 \\
4 & Arizona & 0,84 \\
5 & Vermont & 0,62 \\
6 & California & 0,53 \\
7 & Ohio & 0,49 \\
& South Carolina & 0,18 \\
25 & Virginia & 0,17 \\
26 & Nederland & 0,16 \\
27 & New York & 0,15 \\
28 & Illinois & 0,15 \\
& Wyoming & 0,01 \\
50 & South Dakota & 0,00 \\
51 & & \\
\hline
\end{tabular}

Tabel 7.1 en 7.2 laten zien welke positie Nederland in zou nemen tussen de staten van de VS. Bij de luchtvaart en luchthaven zou Nederland tussen de $24^{\text {ste }}$ en $25^{\text {ste }}$ plaats komen te staan en bij de vervaardiging van vliegtuigen zou Nederland qua werkgelegenheid tussen plaats 26 en 27 belanden. Bij de vervaardiging van vliegtuigen is hierbij uitgegaan van het relatief hoge werkgelegenheidscijfers van de AECMA. Verderop zal worden geanalyseerd wat er zou gebeuren als de luchtvaartsector in Nederland sterk zou gaan groeien en denkbeeldig twee maal zo groot zou worden als thans het geval is. Hoewel zo'n verdubbeling van de werkgelegenheid natuurlijk fors is, laten de tabellen zien dat Nederland na zo'n verdubbeling nog lang niet in de top van de Amerikaanse ranking zou staan.

Eerst wordt echter in tabel 7.3 een beeld gegeven van de relatieve beloning van werkenden in de lucht- en ruimtevaart in de VS. Hierbij wordt het gemiddelde salaris van werkenden met een bepaald opleidingsniveau in de lucht- en ruimtevaart vergeleken met het salaris van werkenden in andere sectoren met dezelfde opleidingsniveau. De Amerikaanse onderwijsaanduidingen zijn vervangen door Nederlandse equivalenten: "less than high school" is geen diploma; "high school" is mavo, havo, vwo; "some degrees" is MBO; en "college degree" is HBO/WO.

De tabel laat zien dat de loonsverdeling in de luchtvaart in de VS een nog sterke spreiding kent dan de toch zeer ongelijke Amerikaanse loonsverdeling in het algemeen. Werkenden zonder diploma verdienen 27 - 38\% minder dan ongediplomeerden in andere sectoren, terwijl de HBO'ers en academici 21 - 27\% meer verdienen. Uitgesplitst naar beroep blijken technici, stewardessen en piloten aanzienlijk meer te verdienen dan werkenden met een vergelijkbaar opleidingsniveau, maar verdienen balie-medewerkers juist minder. Omdat in het algemeen het salaris een 
redelijke indicator is van de competenties van de betrokkenen, kan geconcludeerd worden dat in de luchtvaart in de VS laaggeschoolden werken met juist zeer lage competenties, terwijl juist hooggeschoolden worden aangetrokken met meer competenties dan gemiddeld. Kennelijk is er binnen de luchtvaart aan de ene kant sprake van zeer eenvoudig werk, waar bijna geen kwalificaties voor vereist zijn, terwijl aan de andere kant behoefte bestaat aan de beste academici.

Als deze verhouding in Nederland hetzelfde ligt, maar het niet mogelijk is om de lonen zo sterk uiteen te laten lopen, zal het moeilijk zijn om mensen met zeer lage kwalificatieniveaus te werven, terwijl die toch zeer goed zouden passen binnen het pallet aan werkzaamheden dat zich in de lucht- en ruimtevaart voordoet.

\section{Tabel 7.3}

Procentuele salarisverschillen tussen werkenden in de luchtvaart en vliegtuigbouw per opleidingsniveau in de VS

\begin{tabular}{lcc}
\hline & $\begin{array}{c}\text { Luchtvaart } \\
\text { \% salarisverschil }\end{array}$ & $\begin{array}{c}\text { Vliegtuigbouw } \\
\text { \% salarisverschil }\end{array}$ \\
\hline Geen diploma & -27 & -38 \\
Mavo, havo, vwo & +6 & +13 \\
MBO & +4 & +11 \\
HBO/WO & +21 & +27 \\
& & Bouw \\
& Luchtvaart & \% salarisverschil \\
& \% salarisverschil & +19 \\
\hline Technicus & & - \\
Balie-medewerkers & +22 & - \\
Steward(ess) & -18 & - \\
Piloot & +36 & \\
\hline
\end{tabular}

Deze loonsverschillen tussen bepaalde functies in de lucht- en ruimtevaart en werkenden met een dezelfde opleiding, leeftijd en geslacht is ook per staat afzonderlijk gemaakt. Het blijkt bij bepaalde beroepen, dat naarmate de luchtvaart of de vliegtuigbouw een groter aandeel hebben van de werkgelegenheid in een staat, deze loonpremie stijgt. Op basis van dit verband tussen de omvang van de lucht- en ruimtevaart en de lonen, is gesimuleerd hoe de salarissen in de lucht- en ruimtevaart zouden veranderen als in Nederland de lucht- en ruimtevaart in omvang zou verdubbelen. Hierbij zijn twee kanttekeningen van belang. Doordat in de VS een vergelijking wordt gemaakt tussen staten in niet een vergelijking in de tijd, heeft de vergelijking betrekking op arbeidsmarkten die in de meeste gevallen al sinds langere tijd van elkaar verschillen qua omvang van de lucht- en ruimtevaart. Als gevolg hiervan hebben jongeren bij hun opleidingskeuze rekening kunnen houden met de plaatselijke arbeidsmarktsituatie en is ook de onderwijsinfrastructuur aangepast aan deze vraag. Bij een plotselinge groei zal het aanbod niet onmiddellijk reageren en zal de onderwijsinfrastructuur zich nog moeten aanpassen en daarom kunnen op korte termijn aanzienlijk omvangrijkere effecten van een forse groei worden verwacht. De 
cijfers die we hier presenteren moeten daarom worden gezien als lange-termijneffecten. Daarnaast is de afbakening van regionale arbeidsmarkten op basis van staten waarschijnlijk niet volledig adequaat. Als in een bepaald deel van een staat de vraag naar luchtvaartberoepen toeneemt, hoeft dat voor verder afgelegen regio's weinig gevolgen te hebben. Dat betekent dat de resultaten die gevonden worden betrekking hebben op een gemiddelde reactie binnen de staat. In de directe omgeving van een grote luchthaven of een omvangrijke vliegtuigfabriek zullen de salariseffecten mogelijk een stuk omvangrijker zijn.

Tabel 7.4 geeft hiervan een overzicht. Als allereerst gekeken wordt naar de lonen per opleidingsniveau, dan blijkt dat in de luchtvaart alleen de salarissen op mavo, havo, vwo-niveau en de MBO-lonen duidelijk reageren op een toenemende vraag. In de vliegtuigbouw blijken de lonen van HBO'ers en WO'ers zelfs te dalen als de omvang van de luchtvaart toeneemt. Omdat er ook een verschuiving plaatsvindt in het gemiddelde opleidingsniveau lijkt te er op te wijzen dat vliegtuigbouwbedrijven, bij een toenemende vraag steeds minder goed de meest getalenteerde academici kunnen selecteren en daardoor het gemiddelde salaris daalt.

\section{Tabel 7.4}

Voorspelde procentuele toename van de lonen per opleidingsniveau bij een verdubbeling van de omvang van de lucht- en ruimtevaart op basis van een vergelijking tussen de staten in de VS (-: geen significant effect)

\begin{tabular}{lcc}
\hline & $\begin{array}{c}\text { Luchtvaart } \\
\text { \% salarisstijging }\end{array}$ & $\begin{array}{c}\text { Vliegtuigbouw } \\
\text { \% salarisstijging }\end{array}$ \\
\hline Geen diploma & - & - \\
Mavo, havo, vwo & +4 & - \\
MBO & +6 & - \\
HBO/WO & - & -6
\end{tabular}

Deze gegevens over de salarissen per opleidingsniveau hebben echter betrekking op een zeer uiteenlopende groep werknemers. Een groot deel van deze werknemers heeft een beroep dat niet specifiek is voor de lucht- en ruimtevaart en zal dan ook minder merken van veranderingen in de vraag. In tabel 7.5 wordt daarom de loonsontwikkeling van enkele typische lucht- en ruimtevaartberoepen getoond. In dit geval vinden we, zoals verwacht kan worden, in alle gevallen toenames van de Ionen. Deze toename is groter bij de vliegende beroepen dan bij de technici. Dit lijkt te bevestigen dat voor stewardessen en piloten veel minder vergelijkbare alternatieven in andere sectoren bestaan. Als dus eenmaal de groep met een grote belangstelling voor deze beroepen gerekruteerd is, gaan de luchtvaartondernemingen meer en meer mensen werven die een minder uitgesproken belangstelling hebben voor dit vak. Als gevolg daarvan moeten de salarissen stijgen. Voor technici geïnteresseerde jongeren zal, zeker op de lange termijn, de keuze tussen de ene en de andere technische richting niet zo groot zijn. $\mathrm{Er}$ is daarom minder verschuiving in de beloning nodig om deze groep van keuzegedrag te doen veranderen. 
Tabel 7.5

Voorspelde procentuele toename van de lonen per beroepsgroep bij een verdubbeling van de omvang van de lucht- en ruimtevaart op basis van een vergelijking tussen de staten in de VS (-: geen significant effect)

\begin{tabular}{lcc}
\hline & $\begin{array}{c}\text { Luchtvaart } \\
\text { \% salarisstijging }\end{array}$ & $\begin{array}{c}\text { Vliegtuigbouw } \\
\text { \% salarisstijging }\end{array}$ \\
\hline $\begin{array}{l}\text { Technicus } \\
\text { Baliemedewerker }\end{array}$ & +5 & +2 \\
Steward(ess) & +7 & \\
Piloot & +18 (alleen ouder dan 35) & \\
\hline
\end{tabular}

Omdat een toename van de vraag ook kan impliceren dat de groep werkenden die in het betreffende beroep gaat werken van karakter verandert, is ook de gemiddelde samenstelling van de beroepsgroepen in verband gebracht met de omvang van de lucht- en ruimtevaart. Alleen voor stewardessen bleek dat de gemiddelde leeftijd van stewardessen sterk oploopt als de vraag toeneemt. Ook blijkt dat in de VS de leeftijdsgerelateerde salaristoename voor stewardessen veel groter te zijn dan de salaristoename voor vrouwen met een vergelijkbaar opleidingsniveau. De gegevens lijken er daarom op te wijzen dat naarmate vrouwen ouder worden de belangstelling voor het beroep stewardess sterk afneemt en dat luchtvaartondernemingen behoorlijke salariscompensatie moeten bieden om de oudere vrouwen binnen te houden. Als er voldoende aanbod is zal men daarom een voorkeur voor de goedkopere jonge vrouwen hebben. Naarmate de vraag naar stewardessen groter wordt gaat men echter steeds meer over op de strategie om vrouwen toch zo lang mogelijk binnen het bedrijf te houden.

Tabel 7.6

Leeftijdsopbouw van stewardessen in Nederland en de VS

\begin{tabular}{lcc}
\hline & Nederland & VS \\
\hline & & \\
$16-20$ & 0,7 & 2,5 \\
$21-25$ & 21,3 & 9,8 \\
$26-30$ & 26,5 & 10,0 \\
$31-35$ & 23,0 & 13,2 \\
$36-40$ & 9,9 & 21,2 \\
$41-45$ & 5,1 & 14,1 \\
$46-50$ & 13,3 & 14,5 \\
$51-55$ & 1,0 & 10,5 \\
$56-60$ & - & 2,9 \\
$61-65$ & - & 1,3 \\
\end{tabular}

Uit tabel 7.6 komt naar voren dat in de VS veel meer stewardessen boven de 35 werkzaam zijn dan in Nederland. Als in Nederland de vraag naar stewardessen toe zou nemen zou dit dus tot gevolg kunnen hebben dat het daarmee ook voor luchtvaartondernemingen belangrijker wordt om deze vrouwen minder jong uit te laten stromen. 


\section{Conclusies en opzet van het vervolgonderzoek}

Uit dit vooronderzoek komt naar voren dat de arbeidsmarkt in de lucht- en ruimtevaart niet als één geheel kan worden beschouwd, maar dat er verschillende deelmarkten zijn met elk hun eigen kenmerken en problemen.

Zo'n $40 \%$ van de werkgelegenheid in de cluster blijkt beroepen te betreffen die vrij specifiek zijn en met name in deze cluster voorkomen. Het gaat hierbij enerzijds om piloten en stewardessen en anderzijds om technisch personeel. Naast de inhoud van het werk, blijken echter ook de arbeidsomstandigheden bij de luchtvaartbedrijven en de luchthavens sterk af te wijken van de gemiddelde arbeidsomstandigheden in Nederland. De reistijd is lang, er is veel meer sprake van flexibele werktijden, men kan de inhoud van het werk veel minder zelf bepalen, er is vaker sprake van conflicten met de klant en men geeft meer dan gemiddeld aan last te hebben van gassen en dampen. Afgezien van enkele specifieke karakteristieken voor technische bedrijven wijken de arbeidsomstandigheden in de vliegtuigbouw niet sterk af van het Nederlandse gemiddelde.

Het imago van de cluster bij studiekiezers lijkt redelijk met de werkelijkheid overeen te komen. Er zijn ongeveer evenveel schoolverlaters uit de richtingen die opleiden voor de lucht- en ruimtevaart die aangeven dat ze achteraf liever een andere opleiding hadden willen doen, als dat er schoolverlaters uit andere richtingen zijn die na hun eerste ervaringen op de arbeidsmarkt erachter komen dat werk in de luchten ruimtevaart wellicht interessanter voor hen zou zijn geweest. Als iedereen zich vooraf volledig bewust zou zijn geweest van hoe men deze beroepen na afloop van de opleiding zou ervaren, dan zou er per saldo ongeveer evenveel aanbod verloren zijn gaan als er zou worden bijgewonnen.

Bij de stewardessen is het percentage dat na afloop van de opleiding aangeeft spijt te hebben van de opleiding met bijna $60 \%$ wel zeer hoog. Ook gaan veel schoolverlaters van de $\mathrm{MBO}$-opleiding niet in de luchtvaart werken. Analyses lijken er op te wijzen dat de keuze voor het beroep stewardess vrij sterk bepaald wordt door een voorliefde voor dit vak, maar dat veel jongeren niet goed weten wat hen precies te wachten staat. Als bevorderd zou kunnen worden dat men voor dat een opleiding wordt gestart beter op de hoogte is van wat men later in de beroepsuitoefening te wachten staat, zou veel ontevredenheid en uitstroom uit de sector vermeden kunnen worden. Omdat de luchtvaart voor het aanbod van stewardessen ook sterk afhankelijk is van een groep met een sterke voorkeur voor dit beroep, valt te verwachten dat als de vraag sterk toeneemt, ook de beloning sterk zal moeten toenemen. Er zal immers meer en meer geput moeten worden uit potentieel aanbod dat geen sterke voorkeur voor dit beroep heeft. Uit gegevens uit de Verenigde Staten komt naar voren dat inderdaad in staten waar de vraag naar stewardessen veel groter is, aanzienlijk hogere salarissen worden betaald. Bovendien blijkt men, om in deze grotere vraag te kunnen voorzien, maatregelen te hebben genomen om stewardessen tot op veel hogere leeftijd in dienst te houden dan in Nederland gebruikelijk is. 
Het technisch personeel blijkt juist geen sterke voorkeur voor de lucht- en ruimtevaart te hebben. Afgestudeerden van met name de opleiding vliegtuigtechniek in Delft stromen in grote aantallen door naar technische functies, buiten de lucht- en ruimtevaart, een groot deel van het Fokker-personeel is naar bedrijven buiten de sector verdwenen en uit analyses van arbeidsmarktontwikkelingen in de VS komt naar voren dat als de vraag naar technisch personeel toeneemt, zeker op langere termijn, de lonen niet sterk hoeven te stijgen. Kennelijk is de arbeidsmarkt voor vliegtuigtechnici onderdeel van een veel grotere markt voor technisch personeel. Veranderingen in de vraag van het relatief kleine deel dat de lucht- en ruimtevaart beslaat hebben weinig effecten voor de arbeidsmarkt als geheel. De consequentie is wel dat er duidelijk concurrentie is om de technici tussen de lucht- en ruimtevaart en andere bedrijven. Als andere sectoren betere arbeidsvoorwaarden bieden zullen technici snel geneigd zijn daar te gaan werken. Met name als de winstmarges klein zijn, kan dit betekenen dat het moeilijk is voor bedrijven in de lucht- en ruimtevaart om personeel meer te bieden, waardoor er knelpunten in de personeelsvoorziening kunnen ontstaan.

Voor de $60 \%$ werknemers waarvoor de lucht- en ruimtevaart geen specifiek arbeidsmarktsegment lijkt te zijn, springen de uitzonderlijke arbeidsomstandigheden bij de luchtvaartmaatschappijen en de luchthavens het meest in het oog. Daarnaast blijkt uit de gegevens over de VS, dat de lonen van de ongeschoolden in de luchtvaart aanmerkelijk lager zijn dan bij andere sectoren. Waarschijnlijk betreft dit werknemers met zeer lage competenties die elders moeilijk werk kunnen krijgen. Dit lijkt er op te wijzen dat de luchtvaart in de VS een belangrijke rol speelt voor de werkgelegenheid van de onderkant van de arbeidsmarkt. Omdat in Nederland de lonen minder flexibel zijn dan in de VS en uit de genoemde gegevens blijkt dat de luchtvaart relatief ongunstige arbeidsvoorwaarden kent, rijst de vraag of ook in Nederland de mogelijkheid om juist de minst gekwalificeerden werk te geven in de luchtvaart wordt benut. Helaas is het op grond van de beschikbare cijfers vooralsnog niet goed mogelijk meer licht op deze kwestie te laten schijnen.

Om de keuze voor werk in de lucht- en ruimtevaart nader te analyseren, en met name meer te weten te komen over de motieven om voor een dergelijke opleiding of baan te kiezen voordat de keuze is gemaakt, en de beoordeling van de gemaakte keuze nadat men met de beroepspraktijk is geconfronteerd, is het van belang aanvullende gegevens te verzamelen over het studie- en beroepskeuzeproces. In het licht van de genoemde conclusies ligt het voor de hand om dit onderzoek toe te spitsen op drie groepen: stewardessen, hoger opgeleide technici en de ongeschoolde arbeid op Schiphol. Voorgesteld wordt om op basis van een schriftelijke enquête onder ongeveer 300 personen per doelgroep nadere informatie te verzamelen over motieven voor en beoordeling achteraf van de gemaakte keuzes. Op grond van deze enquête kan antwoord worden gezocht op vragen zoals "wat zijn de cruciale factoren die er voor zorgen dat leerlingen zich bij de keuze voor een opleiding tot stewardess realiseren wat dit beroep betekent", "waarom wijken afgestudeerden van WO vliegtuigtechniek zo makkelijk uit naar technisch werk in andere sectoren", en "is het aantrekkelijk voor ongeschoolden om werk te zoeken op Schiphol". 


\section{Literatuur}

AEMCA (2001), Facts en Figures 2000, Brussel.

Becker, G. (1964), Investment in human capital: A theoretical and empirical analysis with special reference to education, NBER.

Borghans, L. (1999), Arbeidsmarktrelevante studie- en beroepskeuzes van jongeren, Tilburg, OSA A168.

Borghans, L. en K. Jacob-Tacken (2000), Kiezen voor de zorg na een zorgopleiding, Tilburg, OSA ZW11.

Borghans, L, H. Heijke en A. de Grip, Labor market information and the choice of vocational specialization, Economics of Education Review, pp. 59-74.

Boreham, N. en T. Arthur (1993), Information requirements in occupational decision making, University of Manchester.

Blonigen, B. en A. Van Kolpin (2002), Technology, agglomeration, and regional competition for investment, NBER working paper 8862.

Ciccone, A. en R. Hall (1996), Productivity and the density of economic activity, American Economic Review, pp. 54-70.

D'Amico, R. (1983), The nature and consequences of high school employment, In: Borus (ed.), Pathways to the future 1, Columbus.

Faber, J en J. Poort (2002), Leven van de lucht; Indirecte economische effecten van het lucht- en ruimtevaartcluster, Nyfer Breukelen.

Fernandez, R. en R. Rogerson (2001), Sorting and long-run inequality, Quarterly Journal of Economics, pp. 1305-1341.

Fiorito, J. en R.C. Dauffenbach (1982), Market and Nonmarket Influences on Curriculum Choice by College Students, Industrial and Labor Relations Review, pp. 88-101.

Freeman, R. (1975a), 'Legal "cobwebs": A Recursive Model of the Market for New Lawyers', Review of Economics and Statistics, pp. 171-179.

Freeman, R. (1975b), Supply and Salary Adjustments to the Changing Science Manpower Market: Physics, 1948-1973. American Economic Review, pp. 27-39.

Freeman, R. (1980), Employment Opportunities in the Doctorate Manpower Market. Industrial and Labor Relations Review, pp. 185-197.

Ginzberg, E. e.a., (1951), Occupational choice, New York.

Gould, E. en D. Paserman (2003), Waiting for Mr. Right: Rising inequality and declining marriage rates, Journal of Urban Economics, verschijnt binnenkort.

Greenberger, E. en L. Steinberg (1986), Part-time employment of in-school youth: An assessment of costs and benefits, Washington DC.

Hansen, W.L., H.B. Newburger, F.J. Schroeder, D.C. Stapleton en D.J. YoungDay (1980), Forecasting the Market for New Ph.D. Economists, American Economic Review, pp. 49-63.

Hotchkiss, L. (1986), Effects of work-time on school activities and career expectations, National Center for Research in Vocational Education.

Holland, J. (1959), A theory of vocational choice, Journal of Counseling Psychology, pp. 35-45.

Huijsman, R., T. Kloek, D. Kodde, en J. Ritzen (1986), An Empirical Analysis of College Enrollment in the Netherlands, De Economist, pp. 181-190. 
Huffman, W, en P. Orazem (1985), An Econometric Model of the Market for New Ph.D.s in Agricultural Economics in the United States, American Journal of Agricultural Economics, pp. 1207-1214.

Kablaoui, B. en A. Pautler (1991), The effects of part-time work experience on high school students, Journal of Career Development, pp. 195-211.

Kodde (1985), Microeconomic Analysis of Demand for Education, proefschrift Rotterdam.

Koning, M., E. Verkade en J. Hakfoort (2002), Gevolgen van uitbreiding schiphol, CPB, Den Haag.

Lewin-Epstein, N. (1981), Employment and attitudes toward working among high school youth, Chicago.

Lewis, M., A. Gardner en P. Seita (1983), High school work experiences and its effects, In: I. Charner en B. Fraser (eds.), Youth and Work, Washington DC.

Loughran, D. (2002), The effect of male wage inequality on female age at first marriage, Review of Economics and Statistics, pp. 237-250.

Meijers, (1995), Arbeidsidentiteit, Studie- en beroepskeuze in de post-industriële samenleving, Samson, Alpen aan de Rijn,

Meyer, R. en D. Wise (1980), The youth employment problem: Its dimensions, causes, and consequences in youth knowledge, Washington DC.

Mincer, J. (1958), Investment in human capital and personal income distribution, Journal of Political Economy, pp. 281-302.

Nishida, Y. (1992), The current situation concerning the selection of occupations according to ability and occupational experiences by junior high school students in Japan, Journal of Career Development, pp. 89-98.

Parsons, F., (1909), Choosing a vocation, Boston, Houghton Mifflin.

Pfann, G., B. Knüppe en B. Kriechel (2001), Onderzoek naar de gevolgen van het faillissement voor de werknemers van de N.V. Koninklijke Nederlandse Vliegtuig Fabrikant Fokker, Fokker Aircraft B.V., en Fokker Administration B.V.: 1996-2000, BIRC, Universiteit Maastricht.

Rogers, C.R. (1951), Client-centered therapy, Boston 1951.

Schultz, T. (1963), The economic value of education, New York.

Silbereisen, R., F. Vondraeck en L. Berg (1997), Differential timing of initial vocational choice: The influence of early childhood familiy relocation and parental support behaviors in two cultures, Journal of Vocational Behavior, pp. 41-59.

Siow, A. (1984), Occupational choice under uncertainty, Econometrica, pp. 631-645.

Stephenson, S. (1980), In-school labor force status and post-high school wage rates of young men, Applied Economics, pp. 134.

Super, D. (1953), A theory of vocational development, American Psychologist, pp. 185-190.

Super, D. (1959), Vocational development: a factor in vocational guidance and counseling, Youth Employment, pp. 6-12.

Veldhuis. J (2002), Concurreren in de Lucht, SEO-Topics, pp. 6-7.

Weerdenburg, L. (1985), Studiekeuze en studievoorlichting: Een onderzoek onder 5e klas VWO-leerlingen in Oost-Nederland, Faculteit Bestuurskunde, Universiteit Twente.

Weerdenburg, L. (1987), Studiestakers en studievoorlichting. Tijdschrift voor Hoger Onderwijs, pp. 133-145. 
Wiegersma, S., (1990) De geschiedenis van het beroepskeuzewerk, Intermediair.

Wieling, M. en L. Borghans (2001), Discrepancies between supply and demand and adjustment processes in the labour market, Labour, pp. 33-56.

Willes, R., en S. Rosen (1979), Education and Self-Selection, Journal of Political Economy, pp. 517-536.

Zarkin, G. (1983), Cobweb versus Rational Expectations Models, Economics Letters, pp. 87-95.

Zarkin, G. (1985), Occupational Choice, An Application to the Market for Public School Teachers, Quarterly Journal of Economics, pp. 409-446. 